\title{
Active Tectonics in Tuscany (Central Italy): Ten Years of Seismicity (2009-2019)
}

\author{
Marcello Viti \\ Dipartimento di Scienze Fisiche, della Terra e dell'Ambiente, Università degli Studi di Siena, Siena, Italy \\ Email: marcello.viti@unisi.it
}

How to cite this paper: Viti, M. (2020) Active Tectonics in Tuscany (Central Italy): Ten Years of Seismicity (2009-2019). International Journal of Geosciences, 11, 613-650.

https://doi.org/10.4236/ijg.2020.1110032

Received: September 22, 2020

Accepted: October 26, 2020

Published: October 29, 2020

Copyright $\odot 2020$ by author(s) and Scientific Research Publishing Inc. This work is licensed under the Creative Commons Attribution International License (CC BY 4.0).

http://creativecommons.org/licenses/by/4.0/ (c) (i) Open Access

\begin{abstract}
Strong earthquakes (moment magnitude $\mathrm{M}_{\mathrm{W}} \geq 5.5$ ) are uncommon in Tuscany and surroundings (central Italy). The last strong seismic event occurred a century ago (September 7, 1920 Garfagnana, $\mathrm{M}_{\mathrm{W}}=6.53$ ). The paucity of seismic instrumental recordings hinders the identification of the tectonic regime active in Tuscany. On the other hand, the geological and geomorphological pieces of evidence collected so far, concerning potential active and capable faults, are scarce, fragmentary and ambiguous. In this work I shed light on the active deformation of Tuscany by using two independent approaches: earthquake source mechanisms and GNSS (GPS) geodetic measurements. I have considered 41 small seismic events $\left(M_{\mathrm{W}} \leq 5.1\right)$ that occurred in the study area during the last decade. The related source mechanisms (retrieved by the Time Domain Moment Tensor method) define a relatively clear picture of the active deformation: extension along the northern Apennine watershed and strike-slip regime within inner Tuscany, up to the Tyrrhenian coast. This pattern broadly agrees with the horizontal strain field reconstructed by the geodetic velocity field. The latter has been constrained by a network of 840 GPS stations located in Italy and neighboring countries, operating in the last 20 years.
\end{abstract}

\section{Keywords}

Seismotectonics, Earthquake Source, Active Faulting, Satellite Geodesy, Northern Apennines, Italian Region

\section{Introduction}

In the last ten years central-northern Italy has been repeatedly hit by severe earthquakes (2009 L'Aquila, $\mathrm{M}_{\mathrm{W}}=6.3 ; 2012$ Po plain $\mathrm{M}_{\mathrm{W}}=6.1,5.9 ; 2016 \mathrm{La}$ tium-Marche-Umbria $\left.\mathrm{M}_{\mathrm{W}}=6.2,6.1,6.6\right)$. These seismic sequences have hig- 
hlighted the fragility of the urban environment, especially with regard to historical town, industrial plants and communication routes. On the other hand, an unprecedented research effort has allowed us to gain many new knowledge on the tectonic processes taking place in the central and northern Italian Apennines. Indeed, the most up-to-date tectonic, geomorphological, seismological and geodetic methodologies have been employed [1] [2] [3] [4] [5].

The above seismic sequences have affected five Italian administrative regions (Abruzzi, Emilia-Romagna, Latium, Marche and Umbria), where about 14 million inhabitants reside (23\% of the entire Italian population). Tuscany borders all the aforementioned regions, except Abruzzi. However, the remoteness of the main shocks from the Tuscan territory has avoided significant damage. In the same period, only two moderate shocks hit north-western Tuscany $\left(2013 \mathrm{M}_{\mathrm{W}}=\right.$ $5.4,5.0[6])$.

The recent seismic activity in the northern Apennines, and the destructive earthquakes that affected Tuscany in the previous millennium, would suggest to shed light on its seismotectonic pattern. Moreover, one should also consider the potentially involved population (over 3.7 million inhabitants) and the vulnerability of the huge cultural heritage housed in cities such as Florence, Pisa, Siena and many other smaller towns [7].

Finally, a complete and coherent model of the active deformation of the central-northern Apennine cannot disregard the Tuscan sector. However, few specific studies tackle this topic, compared to the many works dealing with the Miocene-Pliocene tectono-stratigraphic evolution [8] [9].

The aim of this work is to illustrate a plausible reconstruction of active deformation in Tuscany. First, I present a summary of the current knowledge on the structural setting and related tectonic features (Section 2). Then, I analyze the information concerning the most recent earthquakes which have affected Tuscany and surroundings (Section 3). Finally, I describe the kinematic pattern obtained by satellite geodetic (GPS) measurements (Section 4). In particular, the geodetic strain field is compared with seismic deformation, in order to evaluate their mutual compatibility. The Appendix lists the seismic data that would be cumbersome in the text.

\section{Morphology, Structural Setting and Main Tectonic Features of Tuscany}

\subsection{Tuscan Physiography: Basins and Ridges}

The northern Apennines, which defines the divide between the Tyrrhenian and Adriatic Sea, extends from Liguria to Latium forming a large arc convex towards ENE. The intermediate portion of this orogenic belt constitutes the Tuscan-Emilian-Romagna Apennines (Figure 1).

NE of the Apennines, relief gradually slopes towards the Po Plain and Adriatic coast, through the hilly Frignano, Romagna and Montefeltro belts (Figure 1). Towards the south-west, within the Apennine arc concavity, morphology is 


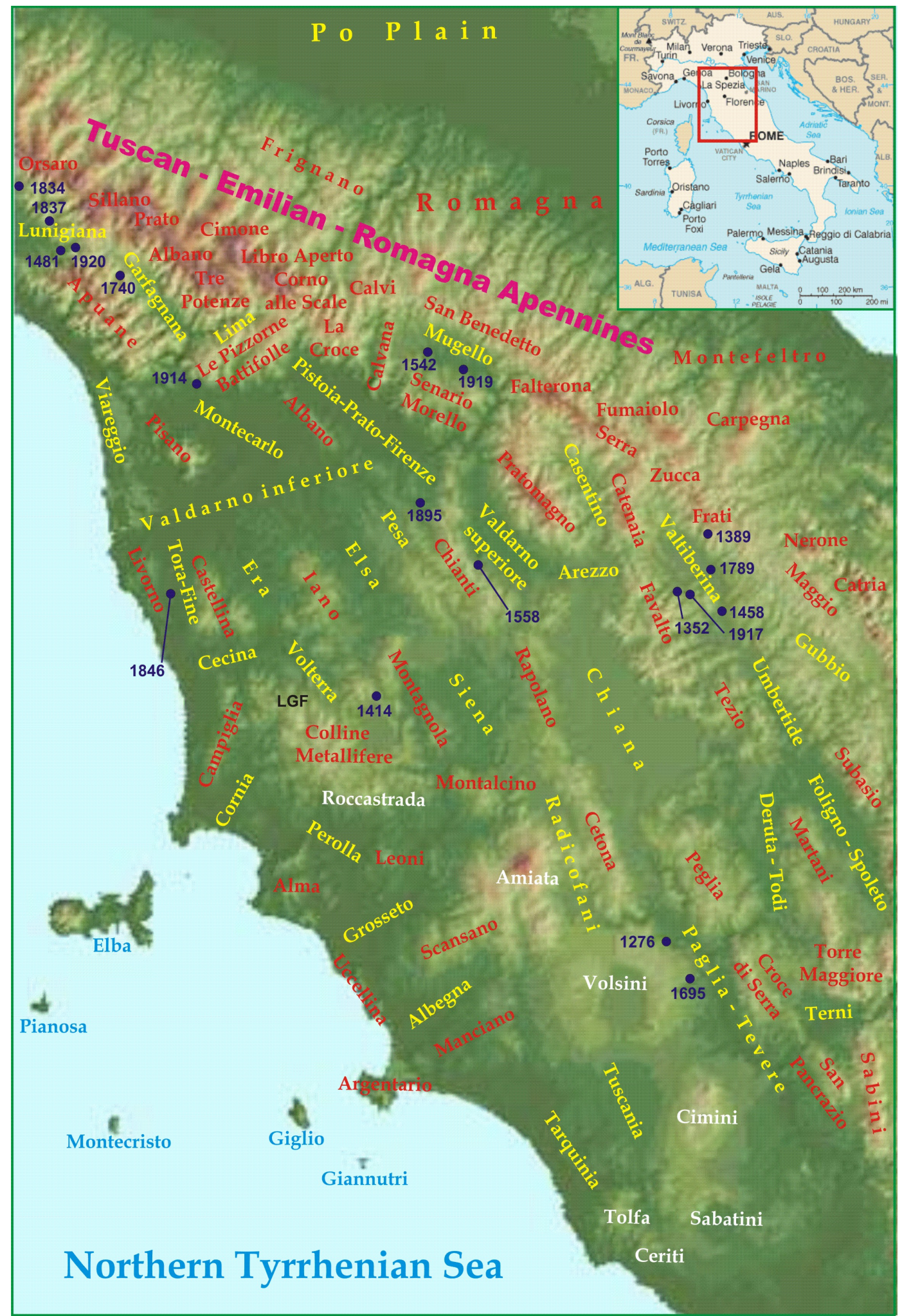

Figure 1. Morphology of the study area (Tuscany and surroundings). Red labels identify the high relief mountain ridges. Yellow labels indicate the low relief sedimentary basins (Upper Miocene-Present). White labels indicate the Pliocene and Pleistocene volcanic complexes. Light blue labels indicate the main islands. Blue dots with the year represent the epicenter of the strong earthquakes occurred after 1000 A.D. $\left(\mathrm{M}_{\mathrm{W}} \geq 5.5\right.$ [6]). LGF = Larderello geothermal field. The geographical location of the study area is shown at the top right. 
more varied. There prominent ridges, mostly NW-SE-oriented, interrupt broad flat or hilly depressions. The maximum topographic elevation occurs in the north-western portion of the Apennines, from Mt. Orsaro to Corno alle Scale (Figure 1). In particular, Mt. Cimone has the maximum altitude of the whole northern Apennines (2165 meters above sea level). The Apuan Alps reach 1 - 2 $\mathrm{km}$ a.s.l. Significant height also has Mt. Falterona (1654 m a.s.l.) and Mt. Fumaiolo $(1268 \mathrm{~m})$, which house the sources of the Arno and Tiber river respectively. SE of these mountains, the Umbrian-Marche Apennines begins, with $\mathrm{Mt}$. $\mathrm{Ne}$ rone (1525 m a.s.l.) and Mt. Catria (1701 m).

The Tuscan territory extends from the Tuscan-Emilian-Romagna Apennine arc to the northern Tyrrhenian Sea. To the south, the border with Latium is marked by Quaternary volcanoes (Mts. Volsini in Figure 1). The Tuscan relief is diversified but not very accentuated. In the innermost sector, Mt. Amiata rises up to $1734 \mathrm{~m}$ a.s.l. Only a few of the other reliefs listed in Figure 1 exceed $1 \mathrm{~km}$ height, mostly in the Colline Metallifere. However, the morphological contrast between ridges and depressions is quite sharp; often it corresponds to important changes in surface geology and structural setting.

The depressions correspond to marine and continental sedimentary basins, developed from the upper Miocene (about 10 million years ago [10]) upon a substrate already deformed by the Alpine-Apennine orogeny [11]. The basin age decreases from the Tyrrhenian coast towards the Apennine belt [12]. Therefore the most eastern (intramontane) basins developed in Pleistocene (Lunigiana, Garfagnana, Mugello, Casentino, Valtiberina in Tuscany; Gubbio, Deruta-Todi and Foligno-Spoleto in Umbria, see Figure 1). In the more ancient, western basins, the thickness of the Upper Miocene-Pliocene filling may exceed $2 \mathrm{~km}$ (e.g., Viareggio, Elsa and Radicofani in Figure 1 [13]). Although both the basins and bounding ridges are generally NW-SE oriented, there exist NE-SW, transversal depressions such as Albegna, Cecina, Cornia, Grosseto and Valdarno inferiore (Figure 1).

The tectono-stratigraphic units outcropping in the ridges are much older $(\mathrm{Pa}-$ leozoic-lower Miocene) than basin filling. These units have been deformed during the Alpine-Apennine orogeny and often bear traces of a regional metamorphism [14]. The oldest formations of the Tuscan sedimentary cover outcrop in the so-called Middle Tuscan Ridge, formed by the Apuan Alps, Mt. Pisano, Iano, Montagnola Senese, part of the Colline Metallifere, Mt. Leoni, Uccellina Mts. and Argentario (Figure 1).

Ridges in western Tuscany were also affected by the Pliocene-Quaternary magmatism, as well as in northern Latium (Roccastrada, Amiata Mt.; Volsini, Cimini, Sabatini and Tolfa Mts. in Figure 1 [15]).

The seismic activity of the above features is not correlated with their age in a simple way. Most of the strong earthquakes $\left(M_{\mathrm{W}} \geq 5.5\right)$ occurred in the intramontane basins (Figure 1). Lunigiana and Garfagnana were hit by 6 strong shocks in 1481 A.D., 1740, 1834, 1837 and 1920 (September 6 and 7). Two historical events are located in Mugello (1542 and 1919). Finally, Valtiberina suf- 
fered 5 major shocks (1352, 1389, 1458, 1789 and 1917).

However, at least 5 strong earthquakes hit ridges and basins of inner Tuscany (Figure 1): Colline Metallifere (1414), Valdarno superiore (1558), Tora-Fine (1846), Chianti/Pesa/Florence (1895) and Montecarlo (1914). Due to closeness with Tuscany, we could also consider the Orvieto (1276) and Volsini Mts. (1695) shocks (Figure 1). This fact suggests that the active deformation of Tuscany is not confined to recent intramontane basins.

On the other hand, some parts of Tuscany appear to be almost aseismic: Casentino, Chiana, Era, Valdarno inferiore and the vast zone extending from Mt. Amiata to Elba Island [6]. Finally, it is worth noting that for a century no strong earthquake has occurred in the study area (1920 Garfagnana, $\mathrm{M}_{\mathrm{W}}=6.53$ ).

\subsection{Structural Setting and Neogenic Evolution}

In the study area, crustal thickness increases from about $20 \mathrm{~km}$ below Elba Island to $22-26 \mathrm{~km}$ in central Tuscany. The Moho depth reaches $50 \mathrm{~km}$ beneath the northern Apennine arc, then it decreases to $26-30 \mathrm{~km}$ near the Adriatic coast [16].

Geophysical survey allowed us to shed light on the architecture of this part of the Apennines [17] [18] [19] [20] [21]. It is a typical thrust-and-fold belt, formed by the progressive stacking of crustal slices. Regional, SW dipping overthrusts make the contact between the slices. They cut the sedimentary cover, dissect the metamorphic basement and perhaps prosecute in the underlying upper mantle as shear zones [20] [21] [22].

The study area belongs to the western edge of the Adriatic plate, whose deformation began in the lower Miocene with the development of eastward migrating thrust belt-foredeep systems [23] [24] After the opening of the northern Tyrrhenian basin in the late Miocene [25], the compressional regime involved an increasingly large area of the Adriatic foreland. Moreover, the related foredeeps were incorporated in the eastward migrating Apennine belt.

Two conflicting interpretations of the study area have emerged over time. The first interpretation provides that since middle Miocene, inner Tuscany was affected by an extensional stress regime. It generated a horst-and-graben (often semigraben) system, corresponding to the ridges and basins indicated in Figure 1 [8] [26]-[38]. Until the lower Pliocene, extension would have occurred by low-angle normal faults (detachments). The subsequent deformation was instead produced by high-angle normal faults, which bound the present depressions [8]. Figure 2 shows the main normal faults reported by the above works.

The alternative interpretation implies that compressional deformation dominated the study area until perhaps the middle Pleistocene [9] [40]-[52]. Indeed, the above Authors recognize the effect of normal faulting from the late Quaternary only. In this context, thrusts and reverse faults would have controlled the development of antiformal folds, corresponding to the ridges shown in Figure 1. The depressions developed as synform or thrust-top basins. Figure 3 shows the main reverse faults, thrusts and folds axes reported in the above works. 


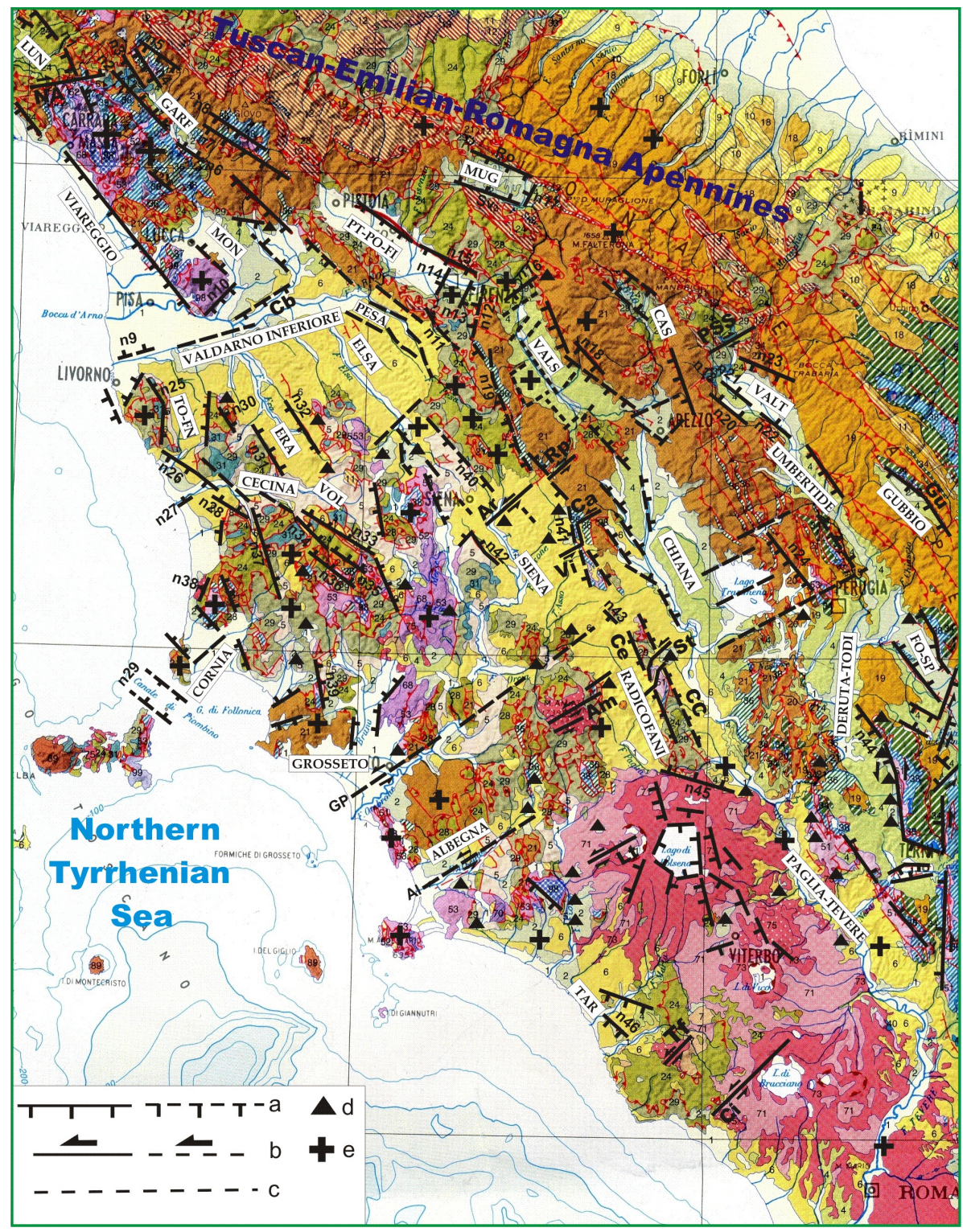

Figure 2. Main normal faults that would have controlled the development of the ridge-and-depression system of Tuscany and surroundings. References for this interpretation are indicated in Paragraph 2.2. The Geological Map of Italy is shown in the background [39]. Labels on white background identify the sedimentary basins shown in Figure 1 (FO-SP = Foligno-Spoleto, GARF = Garfagnana, LUN = Lunigiana, MON = Montecarlo, TO-FN = Tora-Fine, MUG = Mugello, PT-PO-FI = Pistoia-Prato-Florence, VALS $=$ Valdarno superiore, VALT $=$ Valtiberina, $\mathrm{VOL}=$ Volterra $)$. As specified in the text, the depicted faults are not necessarily active or seismogenic. a) Normal fault (dashed if presumed) b) Strike-slip fault (dashed if presumed) c) Presumed fault with undefined kinematics d) Travertine deposit e) Evidence of local uplift. Normal faults cited in the text: $\mathrm{Cb}=\mathrm{Cerbaie}, \mathrm{Ce}=\mathrm{Mt}$. Cetona, $\mathrm{NA}=$ Northern Apuan Alps, Ro = Ronta, Sv = Sieve, VC = Valdichiana. Dextral strike-slip faults: Al = Albegna, GP = Grosseto-Pienza, PSS = Pieve Santo Stefano. Sinistral strike-slip faults: Am = Amiata, Ar $=$ Arbia, $\mathrm{Ca}=\mathrm{Calcione}, \mathrm{Ci}=\mathrm{Ceriti}, \mathrm{Lt}=$ Latera, $\mathrm{Rp}=$ Rapale, $\mathrm{St}=$ Sarteano, $\mathrm{Tf}=$ Tolfa, $\mathrm{Vi}=$ Violante. Normal faults not cited in the text: $\mathrm{n} 1=$ Fivizzano, $\mathrm{n} 2=$ Casciana-Sillicano-Mt. Perpoli, n3 = Verrucole-San Romano, n4 = Corfino, n5 = Mt. Prato, n6 = Bolognana-Gioviano, $\mathrm{n} 7=\mathrm{Barga}$, $\mathrm{n} 8=$ Montefegatesi-Mt. Memoriante, n9 = Coltano, n10 = Vicopisano, n11 = Greve, n12 = Antella, n13 = Bagno a Ripoli-Maiano, n14 = Castello-Scandicci, $\mathrm{n} 15=$ Fiesole, $\mathrm{n} 16=$ Rignano sull'Arno, n17 = Vicchio, n18 = Trappola, $\mathrm{n} 19=$ Montegrossi, $\mathrm{n} 20=$ Monterchi, n21 = Anghiari, n22 = Città di Castello, n23 = Sovara, n24 = Corciano, n25 = Orciano Pisano, n26 = Rosignano Marittimo, n27 = Cecina, n28 = Guardistallo, n29 = Canale di Piombino, n30 = Casciana Terme, n31 = Orciatico-Montecatini Val di Cecina, n32 = Villamagna, n33 = Anqua, n34 = Larderello, n35 = Travale, $\mathrm{n} 36=$ Le Cornate, $\mathrm{n} 37=$ Serrazzano, $\mathrm{n} 38=$ San Vincenzo, n39 = Gavorrano, n40 = Casino, n41 = Rapolano, n42 = Radi, n43 = Pienza, n44 = Monti Martani, n45 = Torre Alfina, n46 = Tarquinia. 


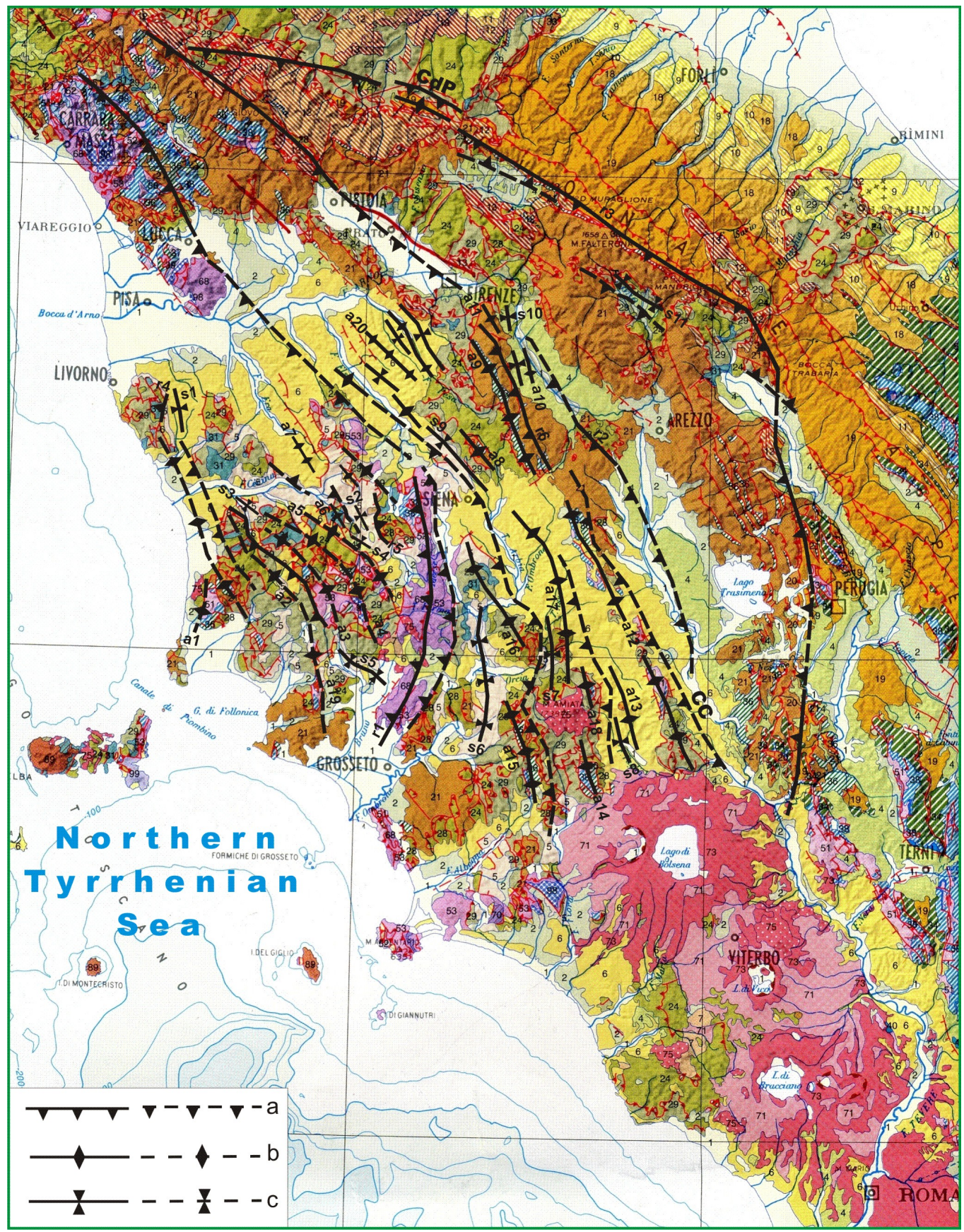

Figure 3. Main compressional features that would have controlled the development of the ridge-and-depression system in Tuscany and surroundings until the middle Pleistocene. References for this interpretation are indicated in Paragraph 2.2. The Geological Map of Italy is shown in the background [39]. As specified in the text, the reported tectonic features shown are not necessarily active or seismogenic. a) Reverse fault or thrust (dashed if presumed) b) axis of antiformal fold (dashed if presumed) c) axis of sinformal fold (dashed if presumed). Features cited in the text: CC = Cetona-Chiana thrust, CdP $=$ Castiglione dei Pepoli thrust and anticline. Antiformal folds (a), sinformal folds (s), reverse faults and thrust (r) not cited in the text: a1 = Campiglia Marittima, a2 = Mt. Pozzacchera, a3 = Prata, a4 = Le Cornate, a5 = Larderello-Travale, a6 = Scapernata, a7 = Volterra, a8 = Vagliagli, a9 = Chianti, a10 = Meleto, a11 = Poggio di Firenze, a12 = Rapolano, a13 = Radicofani, a14 = Castell'Azzara, a15 = Mt. Labbro, a16 = Grotti-Montalcino, a17 = San Quirico, a18 = Poggio Zoccolino, a19 = Gavorrano, a20 = Montespertoli-Tavarnelle; s1 = Val di Fine, s2 = Radicondoli, s3 = Faltona, s4 = Anqua, s5 = Perolla, s6 = Cinigiano, s7 = Val d'Asso-Velona, s8 = Val di Paglia, s9 = Casino, s10 = Palazzolo, s11 = Casentino; $r 1=$ Middle Tuscan Ridge, r2 = Macigno/Cervarola-Falterona, r3 = Cervarola-Falterona/Marnoso-arenacea, r4 = Gabbro, r5 = Santa Maria, r6 = Chianti Mts. 
The aforementioned debate may seem irrelevant to the analysis of seismogenic processes, as it concerns past (pre-Holocene) tectonic phases. However, the gap between the two interpretations may cause serious ambiguity in mapping of tectonic features. For example, the boundary between the Mt. Cetona ridge and Chiana basin is reported as an east-dipping normal fault (VC in Figure 2 [53]), or as a west-dipping thrust (CC in Figure 3 [9]).

In both the above interpretations, most tectonic features are NW-SE directed (Figure 2 and Figure 3). However, some NE-SW features have been suggested also. Such lineaments (e.g., Al and GP in Figure 2) would explain the interruption in the continuity of the sedimentary basins. However, these transverse fault systems are often inferred by stratigraphic and structural considerations, rather than by direct field mapping [13]. More evidence on these features is reported along the northern Apennine arc [54].

An example of the Tuscan transverse structures is the dextral strike-slip fault system located just north of Valtiberina basin (PSS in Figure 2), which however is much older than the basin itself [55].

Recently, some sinistral, transverse fault systems have been described in central Tuscany (Am, Ar, Ca, Rp, St and Vi in Figure 2). These fractures are very recent and probably active, because they are associated with growing travertine deposits [53] [56]-[61] suggest that the western sector of the Larderello geothermal field (LGF in Figure 1) is a pull-apart basin bounded by NE-SW sinistral strike-slip faults. Similar transverse faults have been described in the Pleistocene volcanoes of northern Latium (Ci, Lt and Tf in Figure 2 [62]). [63] recognize the Mt. Amiata strike-slip fault (Am in Figure 2), but they attribute it a dextral kinematics.

Although the faults and folds shown in Figure 2 and Figure 3 are often prominent morphotectonic features, they do not necessarily represent active structure or seismogenic sources. Indeed, the identification of active and capable faults [64] faces several difficulties. As regards Tuscany, it should be considered in its initial phase [63].

\subsection{Geomorphological Constraints: Local and Regional Uplift}

Two important uplift episodes affected the study area since the Upper Miocene. The first episode (middle-late Pliocene) led to the emersion of marine basins, such as Siena and Radicofani in southern Tuscany [65] [66]. The second episode has started in the middle Pleistocene with uplift rates of $1-2 \mathrm{~mm} /$ year. It affected both the northern Apennine arc [67] [68] [69] [70] and inner Tuscany [37] [71] [72]. As Quaternary uplift is possibly linked with active tectonics, Figure 2 indicates the most uplifted zones according to the above works.

In some cases, surface uplift can be a consequence of the emplacement in the crust of plutons and magma chambers [73]. This mechanism has been adopted to explain the current elevation of the Pliocene marine deposits of southern Tuscany, sometimes many hundreds of meters asl [34] [65] [74] [75] However, 
Pliocene-Quaternary magmatism has affected southern Tuscany only [15], so it cannot be invoked for the other uplifted zones. For example, both the Chianti Mts. and the adjacent Siena and Valdarno superiore basins (Figure 1 and Figure 2) have undergone a substantial Quaternary uplift [76]. Likewise, in north-western Tuscany the Apuan Alps acquired their rugged morphology in the Quaternary only [77]. In addition, conspicuous uplift and exhumation rates are estimated both north-west and south-east of the Mugello basin, as well as in the Romagna Apennines [31] [70] [78].

Any interpretation of the active tectonics of the study area must take in due account the evidence of recent uplift, at both the local and regional level.

\subsection{Active Tectonics and Seismicity}

Current compilations of active and seismogenic faults [79] [80] pay little attention to the study area. After the pioneering work of [81], only in recent years the identification of active faults in Tuscany renewed. In particular, the intramontane basins have been investigated: Casentino, Garfagnana, Lunigiana, Mugello, Pistoia-Prato-Florence and Valtiberina (Figure 1 and Figure 2) [48] [49] [82] [83] [84] [85] [86]. [70] looked for active faults in the Tuscan-Emilian-Romagna Apennines. Inner Tuscany has received much less attention so far [56] [58] [63] [87]. This may be due to the fact that the most recent strong earthquakes have hit the outer, intramontane basins (Figure 1).

The active structures identified (more often suggested) by the above studies usually are normal faults (Figure 2). Active reverse faults and folds are instead reported in the Tuscan-Emilia-Romagna Apennines (e.g. CdP in Figure 3).

So far, none of the active faults proposed in the literature has revealed its seismogenic nature, because the last strong earthquake occurred in the study area dates back to a century ago (1920 Garfagnana, Figure 1). In fact, confirming such nature needs accurate detection of the seismic fractures induced by a strong earthquake (usually $M_{W} \geq 6$ ). This actually happened for the Mt. Vettore-Laga Mts. normal fault system after the October, 302016 Norcia earthquake $\left(\mathrm{M}_{\mathrm{W}}=\right.$ 6.6 [88] [89] [90]). On the other hand, the surface distribution of the coseismic fractures is often difficult to reconstruct when many individual fault segments are involved, as usually happens for normal faulting [91] [92] [93] [94] [95].

In absence of coseismic deformation, the seismogenic nature of a fault remains largely speculative. Field researchers working in active tectonics often overlook the distinction between coseismic and aseismic slip of outcropping faults. Several aseismic faults are known, including the Hayward fault in California and the Ismetpasa segment of the North Anatolian fault in Turkey [96] [97]. However, the documentation is scarce for the Italian region [98]. Moreover, discrimination between seismic and aseismic slip may be surprisingly difficult without the support of specific laboratory tests [99] [100].

Various difficulties hinder the identification of active faults (both seismic and aseismic) by geological and geomorphological survey. First, an unknown frac- 
tion of the active fault population is represented by buried shear fractures, which may have a weak morphological expression at the surface [101] [102] [103] [104]. For example, the buried reverse faults responsible for the May, 2012 Po Plain earthquakes did not produce surface faulting [105].

Some complications can also occur in the presence of marked fault scarps with measurable kinematic indicators:

1) An ancient tectonic feature can be mistakenly recognized as an active fault. For example, [106] refute the existence of a normal fault in the Val d'Agri (southern Apennines), which [107] consider as the source of the 1857 large earthquake $\left(M_{\mathrm{W}}=7.12[6]\right)$. In this case, the detected triangular facets are not the traces of a normal active fault. Instead, they probably are flatirons, i.e. eroded remains of a limb of an ancient fold [106]. In fact, triangular facets may appear on any tectonic feature (normal fault, reverse fault and fold) and by selective erosion also [104] [108].

2) The morphological prominence of the fault scarp is not always a reliable indicator of its recent/present activity. A well-known example is the Gubbio fault ( $\mathrm{Gu}$ in Figure 2), which bounds to the east the Gubbio intramontane basin. This $22 \mathrm{~km}$ long normal fault dips $60^{\circ}-70^{\circ}$ to the west and forms a steep morphological escarpment, towering on the underlying flat basin. The cumulative throw, occurred in several stages since the Upper Miocene, reaches $2000 \mathrm{~m}$ [109]. However, evidence about the present activity of this fault is scarce. Only a strong earthquake has occurred near Gubbio $\left(1984, \mathrm{M}_{\mathrm{W}}=5.6\right.$ [6] and the role of the Gubbio fault is still debated. In fact, during that shock no coseismic fracture was observed near the fault [110] [111].

[104] also advises caution in assessing the recent activity of fault escarpments by morphotectonic analysis only. For example, [63] suggest the present activity of the Mt. Cetona normal fault (Ce in Figure 2), which bounds to the east the Radicofani basin. They also estimate a recent slip rate of about $0.6 \mathrm{~mm} /$ year. On the contrary, [53] state that this Pliocene fault is now inactive, since it is dissected by a Quaternary strike-slip fault system (St in Figure 2).

3) The so-called selective erosion, due to the different weathering of outcropping formations, can generate forms simulating normal active faults [108]. For example, the alleged active Cerbaie fault ( $\mathrm{Cb}$ in Figure 2), located in the Valdarno inferiore basin, could actually be an erosional landscape [108].

4) A large landslide can generate a shallow deformation pattern simulating normal, strike-slip and reverse faults in the detachment area, sides and toe of the landslide respectively [112]. [113] discuss several features misinterpreted as active normal faults in the central Apennines.

Due to the above problems, mapped active faults may not correspond to actual seismic sources. For example, two large earthquakes hit the Mojave Desert (eastern California) in 1992 (Landers, $\mathrm{M}_{\mathrm{W}}=7.3$ ) and 1999 (Hector Mine, $\mathrm{M}_{\mathrm{W}}=$ 7.1). These shocks produced a pattern of coseismic faulting that significantly differs from the previously mapped active faults (Figure 4.27 by [104]). 


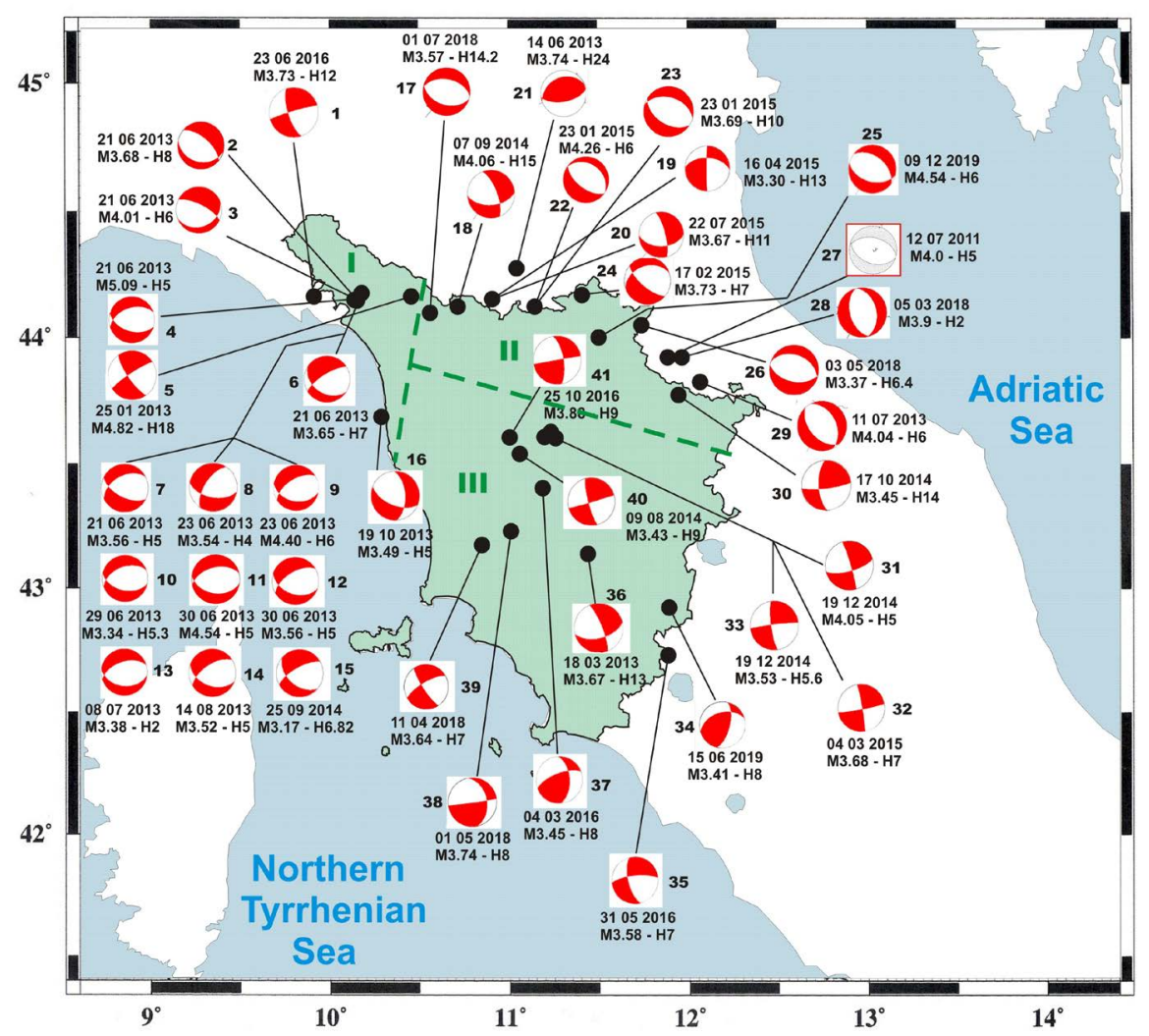

Figure 4. Source mechanism of earthquakes occurred in the last decade in Tuscany and surroundings. Data taken from the INGV archive (http://terremoti.ingv.it/tdmt). The epicenter of each seismic event is indicated by the black dot connected to the stereographic projection of the focal sphere. The order number (from 1 to 41), date, moment magnitude $(\mathrm{M})$ and hypocenter depth $(\mathrm{H})$ are provided also. The nodal planes and the poles of $\mathrm{P}$ and $\mathrm{T}$-axes are shown in Figure $\mathrm{A} 1$ of the Appendix. The parameters of the nodal planes are shown in Table A1 of the Appendix. The dashed green lines delimit the three sectors discussed in the text: I) north-western Tuscany II) Tuscan-Emilian-Romagna Apennines III) inner Tuscany. The green shape identifies the territory of Regione Toscana.

In brief, the search for seismogenic structures by morphotectonic analysis should be supported by independent methodologies. In the next section I consider the use of the source mechanisms of small earthquakes that have recently occurred in the study area.

\section{Source Mechanism of Recent Earthquakes}

\subsection{State of the Art}

Global, national and local seismometric networks make possible recording many seismic events, most of which can be defined small earthquakes $\left(M_{W} \leq 5\right)$. The analysis of the micro-seismicity provides basic information in order to define the seismotectonic pattern of an actively deforming zone [114]. This kind of investigation is particularly important where tectonic deformation is slow and strong earthquakes are relatively rare. Furthermore, using micro-seismicity has the obvious advantage of dealing with actual (albeit small) seismic slip events. 
The earthquake source mechanism (ESM), representing the geometry of the seismic fracture, is fully described by the seismic moment tensor [115]. As earthquakes are basically slip events on shear fracture, the seismic moment tensor is dominated by the double couple solution, represented by a couple of nodal planes and the related tensor eigenvectors (B, $\mathrm{P}$, and $\mathrm{T}$ axes).

A set of ESMs allows us constraining the stress and strain tensors in the crustal volume affected by seismic activity [116] [117] [118]. Small earthquakes contribute little to the overall deformation of a given crustal volume [119]. However, the seismic strain style (i.e. the direction of the principal strain axes and the ratio between their amplitudes) is similar for large earthquakes and for small shocks. Therefore, micro-seismicity can be used to constrain the seismotectonic pattern [120]. Furthermore, small earthquakes re-distribute elastic stress on the involved faults, thus influencing the development of future seismicity [121].

Some previous works deal with the micro-seismicity of the study area, although the analysis is often limited to specific sectors. For example, a local seismometric network has provided several ESMs for the Larderello geothermal field (LGF in Figure 1 [122] [123]). In particular, [124] considered 190 small seismic events $(0.5<M<3.0)$, occurred in the western part of LGF from 1994 to 2000. The stress regime obtained inverting those ESMs is compatible with an active, NE-SW strike-slip fault, which could dissect at depth the NW-SE normal faults mapped in the Colline Metallifere zone (from n. 33 to n. 37 in Figure 2). Furthermore, the emplacement of the Larderello granitoid pluton would have been favored by a deep-seated, NE-SW strike-slip fault [52] [75].

[125] [126] consider the Apuan Alps and the adjacent depressions of Lunigiana and Garfagnana in north-western Tuscany. [127] describe the source mechanism of small earthquakes $\left(\mathrm{M}_{\mathrm{W}} \leq 4.7\right)$ occurred since 1992 until 2007 in a zone embracing the Romagna Apennines, Casentino and Valtiberina basins.

[128] consider the micro-seismicity $(2.5<\mathrm{M}<4.8)$ occurred in Italy in the period 1988-1995. The EMSs were obtained by the first-arrival polarity method. Then, [129] procedure was adopted to constrain the stress regime in various sectors of the Italian region. The two sectors named "Northern Tuscany" and "Pery-Tyrrhenian" include north-western Tuscany and the Tyrrhenian coast of Tuscany and Latium respectively. In both sectors, the estimated stress regime is extensional, with a ENE-WSW directed, sub-horizontal minimum compression axis $\left(\sigma_{3}\right)$. In the stress regime map elaborated by [130] the study area is characterized by pure extension, with NE-SW $\sigma_{3}$.

However, the determination of the stress regime by ESM inversion is based on some assumptions that are not easily verifiable [117]. In fact, the inversion procedures require homogeneity of rock mechanical properties and uniformity of the stress state in the crustal volume considered. Furthermore, the source mechanisms should be independent each other, which is in contrast with the fault interaction expected by the rock elastic behavior [121].

[131] considered the seismicity of the central-northern Apennines recorded in 
the time interval 1981-2002 [132]. In particular, 424 ESMs were classified into 5 classes (normal, trans-tensional, strike-slip, trans-pressional and reverse) according to the fault direction, fault dip and slip vector. This analysis shows that normal and reverse faults represent only $40 \%$ of the total, while sinistral and dextral strike-slip faults reach $28 \%$. Furthermore, the proportion of normal faults significantly decreases (from $33 \%$ to $4 \%$ ) as hypocenter depth increases. [131] suggest that the typology and spatial distribution of ESMs does not support the conclusion drawn by [128] [130] who clearly distinguish an outer Apennine belt (where compression prevails) from an inner belt dominated by extension. Finally, [131] include inner Tuscany in their "West Central" sector, where available ESMs are not sufficient to clearly constrain a seismotectonic pattern.

So far, seismological evidence has not provided a widely shared interpretation of the active tectonics of Tuscany. In the next section I will discuss a new set of ESMs that could allow us to approach that objective.

\subsection{New Information from Micro-Seismicity}

Since 2005, the Italian Istituto Nazionale di Geofisica e Vulcanologia (INGV) has been processing seismic waveforms by the Time Domain Moment Tensor (TDMT) procedure. This concerns earthquakes having magnitude $\mathrm{M}_{\mathrm{W}} \geq 3.5$, whose epicenter in located in Italy and neighboring countries [133].

The TDMT procedure is based on the algorithm developed at the University of Berkeley, California (http://seismo.berkeley.edu/ dreger/mtindex.html), which inverts the three-component waveforms recorded by broadband seismic stations. The synthetic seismograms used for seismic moment tensor inversion are calculated by means of a laterally homogeneous, $1 \mathrm{D}$ velocity model calibrated on a regional basis. The focal mechanism representation is obtained with the procedure developed by [134].

Using the ESMs derived by TDMT analysis has two important advantages: 1) they have been obtained from recent seismic recordings, which benefited from the modernization of the Italian seismometric network 2) the seismic moment tensor inversion methodology is common for all data considered. This eliminates the problems related to the use of ESMs having heterogeneous quality, as they were retrieved by different procedures [49] [131] [135].

Available ESMs can be downloaded from the dedicated website (http://terremoti.ingv.it/tdmt). Therefore, I have collected the source mechanism of seismic events occurred in Tuscany and surroundings from 2009 to 2019. The spatial distribution of the data collected from the TDMT catalog is shown in Figure 4. The date, moment magnitude $\left(3.17<\mathrm{M}_{\mathrm{W}}<5.09\right)$ and hypocenter depth $(2<\mathrm{H}<24 \mathrm{~km})$ are reported close to the source mechanism symbol. Moreover, I have assigned to each datum an order number ranging from 1 to 41 . Epicenter coordinates and basic nodal plane angles are reported in Table A1 of the Appendix. For each ESM, the stereographic projection of the focal sphere, with the poles of T and P axes, is shown in Figure A1 of the Appendix. 
The strain style indicated by the ESMs suggests dividing data into 3 subsets, corresponding to 3 different sectors of the study area (I, II and III in Figure 4). Data numbering follows this grouping. Sector I (16 ESMs from n.1 to n.16) includes north-western Tuscany, with the Apuan Alps and the Lunigiana and Garfagnana basins (Figure 1 and Figure 2). Sector II (14 ESMs from n.17 to n.30) includes the Tuscan-Emilian-Romagna Apennines. Sector III (11 ESMs from No.31 to No.41) corresponds to inner Tuscany.

\subsubsection{Sector I}

The ESMs included in this sector are extensional (sub-horizontal $\mathrm{T}$ axis) but two. A strike-slip solution (sub-horizontal $\mathrm{T}$ and $\mathrm{P}$ axis) falls in Lunigiana (n.1, 23/06/2016 Santo Stefano di Magra). The other strike-slip mechanism is located in northern Garfagnana (n.5, 25/01/2013 Castiglione di Garfagnana). These two solutions are quite similar, with E-W P-axis and N-S T-axis. Hypocenter depth is larger than $10 \mathrm{~km}$ for both shocks.

Events n.2 and 3 (21/06/2016 Casola in Lunigiana) occurred in the Lunigiana basin (Figure 1). The mechanism is extensional with NE-SW T-axis.

Datum n.4 corresponds to the largest shock of the whole ESM set (21/06/13 Equi Terme, $M_{W}=5.09$ ). The epicenter falls in the same area hit by the 1481 and 1920 strong earthquakes (Figure 1). The mechanism is clearly extensional, with roughly N-S T-axis. Data from n.6 to no.15 are the aftershocks of n.4. They show very similar ESMs, analogous to those of the main shock. It is worth noting note that the above ESMs are compatible with the location, direction and kinematics of the Northern Apuan Alps fault described by [86] (NA in Figure 2).

Datum n.16 is located near the Tyrrhenian coast in the Viareggio basin (Figure 1 and Figure 2). The mechanism is still extensional, but the $\mathrm{T}$ axis is directed ENE-WSW.

In summary, in sector I shallow events $(\mathrm{H}<10 \mathrm{~km})$ have an extensional mechanism, while deeper shocks show strike-slip seismic strain.

\subsubsection{Sector II}

In this sector, the epicentres are located mostly along the northern Apennine arc, near the watershed between the Tyrrhenian and Adriatic Sea. Data n.17 and 18 (01/07/2018 Pievepelago and 07/09/2014 Abetone) fall in the Mt. Cimone-Val di Lima area (Figure 1). ESMs are extensional and trans-tensional, with N-S to NE-SW T-axis respectively. Data n.19 and 20 (16/04 and 22/07 2015 Lizzano in Belvedere) are trans-tensional, with a NE-SW T-axis.

Datum n.21 (14/06/2013 Castel d'Aiano) has a hypocenter depth of $24 \mathrm{~km}$ and a compressional mechanism, with a NNW-SSE, sub-horizontal P-axis. It is worth noting that the Monghidoro moderate shock (09/14/2003, $\mathrm{M}_{\mathrm{W}}=5.3, \mathrm{H}=$ $20 \mathrm{~km}$ ) occurred slightly further north at comparable depth, and has the same compressional source mechanism [136].

Data n. 22 and n. 23 (23/01/2015 Castiglione dei Pepoli) are quite interesting. The observed extensional strain, with NE-SW T-axis, is in stark contrast to the 
hypothesis of active compression proposed by [70] on the basis of morphotectonic evidence (CdP thrust-anticline system in Figure 3).

Event no.24 (17/02/2015 Firenzuola) shows an extensional mechanism. Datum n.25 (09/12/2019 Scarperia and San Piero) is the most recent ESM. It is located in the Mugello basin. The strain style is clearly extensional, with NE-SW $\mathrm{T}$-axis. The direction of the nodal planes is compatible with the active faults suggested in the literature (Ro and Sv in Figure 2 [49]). However, the small magnitude $\left(\mathrm{M}_{\mathrm{W}}=4.54\right)$ makes coseismic surficial faulting unlikely.

Earthquakes no.26, 27, 28 and 29 (03/05/2018 Tredozio, 22/07/2011 and 05/03/2018 Santa Sofia, 11/07/2013 Verghereto) have epicentres located in the Romagna Apennines, close to the border with Tuscany. The mechanism of the above events is extensional, with T-axis trending from NNE-SSW to NE-SW. [127] presented similar results by considering the small earthquakes that occurred in the same area from 1997 to 2005. These ESMs contrast both the active reverse faulting suggested by [70] and the trans-pressional strain regime proposed by [49].

Datum n.30 (17/10/2014 Chiusi della Verna) falls in the Alpe di Catenaia ridge, which separates the Casentino and Valtiberina basins (Figure 1). The strain regime is roughly strike-slip, with a NW-SE P-axis and NE-SW T-axis.

In summary, the shallow seismicity of sector II highlights an extensional style of seismic strain, with a sub-horizontal, roughly NE-SW T-axis. As noted for Sector I, shocks deeper than $10 \mathrm{~km}$ have a strike-slip or compressive ESM.

\subsubsection{Sector III}

The earthquakes occurred in Sector III are mostly shallow and affect the main ridges and depressions of inner Tuscany. Data n.31, 32 and 33 (19/12/2014 Greve in Chianti, 04/03/2015 Tavarnelle Val di Pesa and 19/12/2014 San Casciano Val di Pesa) are located between the north-western Chianti Mts. and Pesa basin (Figure 1). They show a strike-slip ESM, with NW-SE P-axis and NE-SW T-axis. Event n.34 (15/06/2019 Mt. Cetona) falls on the edge of the Radicofani basin (Figure 1). The mechanism is compressional, with a NW-SE $\mathrm{P}$ axis and sub-vertical T-axis. Active compression in that area disagrees with the alleged activity of the Mt. Cetona normal fault (Ce in Figure 2), suggested by [63].

Earthquake n.35 (31/05/02016 Acquapendente) is located near the Latium-Tuscany border. The mechanism is trans-tensional, with NE-SW T-axis.

The epicenter of the shock n.36 (18/03/2013 Buonconvento) is located in the Siena basin (Figure 1). The trans-tensional mechanism shows a NE-SW T-axis.

Event n.37 (04/03/2016 Colle di Val d'Elsa) is located in the Elsa basin (Figure 1) and has a trans-pressional mechanism, as indicated by the nodal planes parameters reported in Table A1 of the Appendix.

Data n.38 and 39 (01/05/2018 Castelnuovo Val di Cecina and 11/04/2016 Monterotondo Marittimo) are located in the northern Colline Metallifere ridge, within the Larderello geothermal field (LGF in Figure 1). Both the ESMs are roughly strike-slip, with NE-SW T-axis and NW-SE P-axis. This strain style is 
compatible with the stress state described for that zone by [124].

Events n.40 and 41 (09/08/2014 Castelfiorentino and 25/10/2016 Certaldo) took place in the Elsa basin (Figure 1). The mechanism is strike-slip with NW-SE P-axis.

ESMs of sector III show a remarkable similarity as regards the orientation of the nodal planes and the $\mathrm{P}$ and $\mathrm{T}$ axes (Figure 4 and Table A1). The strain style is mostly strike-slip, while no solution indicates the pure extensional regime observed in sector II.

These information cast doubt on the activity of the normal faults of southern Tuscany, suggested by [63]. Moreover, the purely extensional stress regime proposed for Tuscany [128] [130] disagrees with the above ESMs. Instead, such data suggest that the seismic deformation of Sector III is caused by shallow strike-slip faults, such as those recognized by geological survey (Am, Ar, Ca, Rp, St and Vi in Figure 2 [53] [58]). However, the epicenter of the earthquakes discussed above is quite distant from the aforementioned faults. In addition, recent seismicity affected zones as the Colline Metallifere and the Elsa and Pesa basins, where no strike-slip faults have been described so far. Thus, the link between actual seismogenic faulting and mapped active/capable faults remains weak for inner Tuscany.

In brief, the source mechanisms of recent earthquakes clearly indicate that along the northern Apennine arc (Sectors I and II in Figure 4) the strain style is extensional in the shallow crust $(\mathrm{H}<10 \mathrm{~km})$ and strike-slip or compressional at greater depth. This feature supports the conclusions drawn by [131]. Within inner Tuscany, the strain style is mainly strike-slip, with a roughly NW-SE P-axis and NE-SW T-axis.

In the next paragraph I will discuss the implications of the satellite geodesy measurements, with particular attention to the horizontal strain field.

\section{Space Geodesy: Further Constraints on Active Deformation}

Satellite geodesy networks such as the Global Navigation Satellite System (GNSS) or Global Positioning System (GPS) allow researchers to investigate plate kinematics at global, regional and local scale [137]. The geodetic velocity field has long been used to constrain the seismotectonics of the Italian region [138] [139] [140] [141]. Particularly interesting is the determination of the strain field from geodetic measurements [140] [142] [143] [144]. Comparing geodetic and seismic strain, as indicated by ESMs, can be very informative [145] [146].

\subsection{Analysis of the Geodetic Measurements}

In this paragraph I describe the treatment of the geodetic measurements carried out in many GPS sites located in Italy and neighboring countries. Data come from 840 GPS permanent stations, whose location is shown in Figure 5. Since the treatment of GPS time series is detailed by [140] [141] [144]. I report here only basic information. 


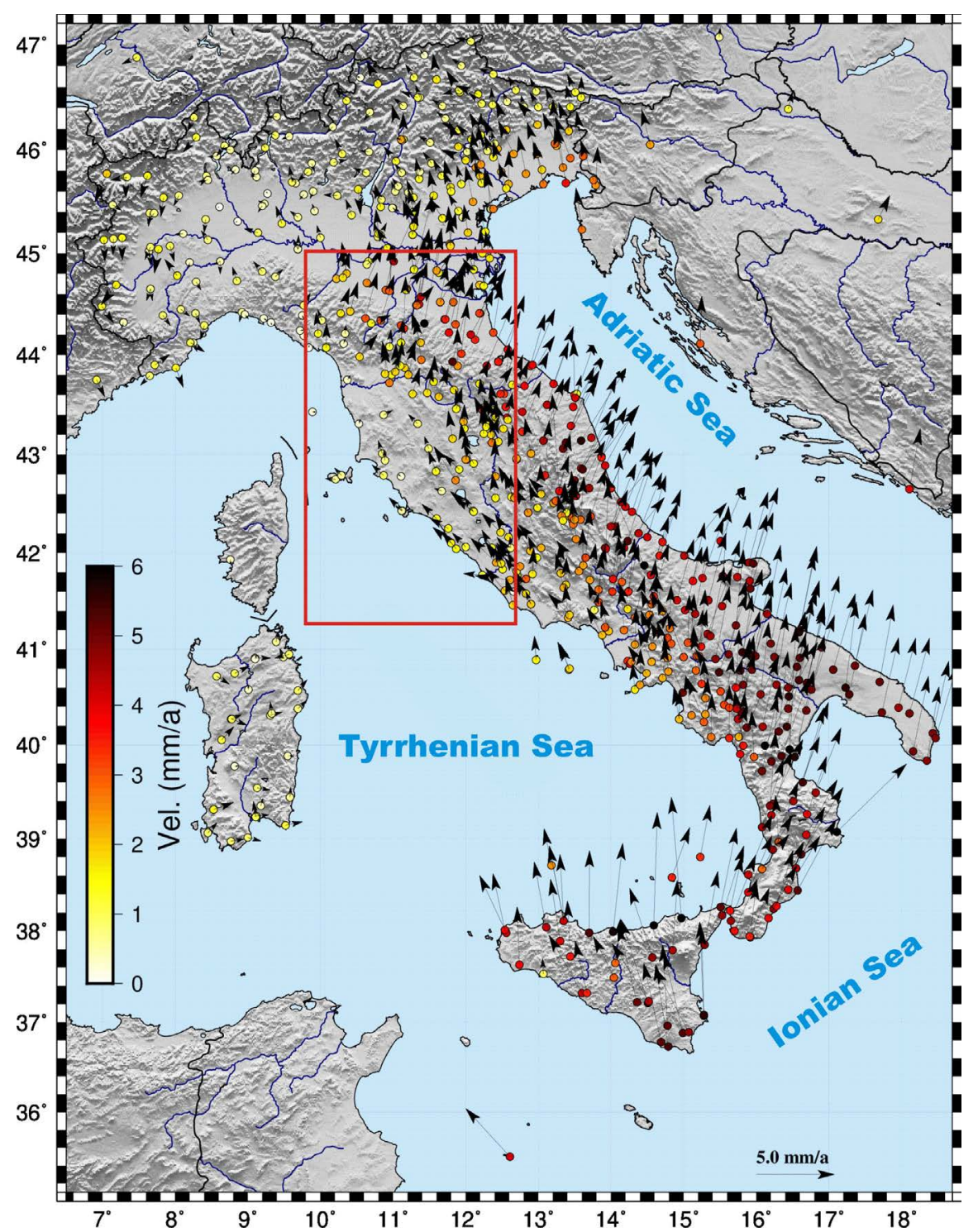

Figure 5. GPS horizontal velocity field for the study area. Velocity vectors are computed with respect to the Eurasian plate, whose absolute motion (i.e. with respect to the Earth center of mass) is provided by [151]. Only stations with observation time interval $\geq 2.5$ years were considered for velocity estimate. Circles indicate the location of GPS stations. The color of the circles depicts the velocity amplitude according to the chromatic scale shown on the left. The red box indicates the zone where the horizontal strain rate is shown (Figure 6). See text for details about the analysis of GPS measurements.

The GPS permanent stations belong to various geodetic networks, managed by research institution, professional organizations and commercial companies. However, all stations use good quality, dual frequency instruments. In addition, the adopted support always ensures tight coupling between the antenna and ground or building walls. [147] shown that the different ways of installing and managing GPS stations do not entail neither systematic noise increase in time series, nor important signal distortions. For this reason, the observations acquired by professional and commercial stations can be used for scientific studies also. 
Data were analyzed with the GAMIT/GLOBK software [148] [149]. The International GNSS Service (IGS) provide information about the orbit of GPS satellites, data on Earth rotation and revolution, and parameters for modeling the electronic center of antennas. Due to the large number of stations, I adopted the distributed processing proposed by [150]. The initial part of the analysis is performed by dividing the initial network (all stations), into several subnets (clusters) containing a smaller number of sites. Therefore, the network was divided into 45 clusters. I inserted in each cluster the observations of at least 6 stations belonging to the European EUREF network, which guarantees measurement quality. Then, the daily solutions of all the subnets were combined by using the position of the common stations inserted in the different clusters as a constraint. This was done on the daily solutions of the subnets, thus obtaining a general daily solution.

As the different daily solutions may not be expressed in the same system, each solution must be referred to a single reference system. For this reason, the observations of 16 stations located around the Italian region were included in the subsequent analysis. Indeed, IGS provides position and velocity of these stations, referred to the International Terrestrial Reference Frame (ITRF). Consequently, the daily solutions of the geodetic network have been included in the updated ITRF2014 version, by using the position and velocity data provided by [151].

In order to insert each station in the ITRF2014, a 7-parameter Helmert transformation (3 translations, 3 rotations and a scale factor) was carried out, by means a weighted least squares approach which compares the calculated station coordinates with those provided by IGS. Finally, I obtained the time series of the daily position of each station: north component (measured from Equator), east component (measured from the Greenwich meridian) and elevation component (height on the WGS84 reference ellipsoid).

Then, the daily time series of the above components have been elaborated by [140] [141] procedure, in order to determine the velocity of the vertices of the geodetic network. The time series of each component was analyzed independently of the others, in order to eliminate any anomalous data (outliers) by using a specific software [152]. Once the anomalous data were eliminated, I obtained a first estimate of the station velocity, along with any discontinuities eventually caused by maintenance, or by nearby earthquakes. The above parameters, estimated by means of a weighted least square approach, were used to determine the theoretical time pattern of the three components of the position of each station. This theoretical trend is subtracted from the real trend, yielding a time series of residual. This residual series is then analyzed using a Lomb-Scargle approach [153] [154] in order to estimate the series frequency spectrum. Then, the spectrum is analyzed to determine the statistically significant periods of the 5 main seasonal signals. This search is carried out in the time interval ranging from 1 month to half of the entire observation period of the station, to avoid aliasing or indetermination problems.

The time series of the 3 components (without outliers) are analyzed again to 
determine a new estimate of the velocity, discontinuities, amplitude and phase of the 5 seasonal signals whose periods were estimated during the spectral analysis. Then a new theoretical daily trend is estimated and subtracted from the real one, to obtain a new time series of residuals. Finally, this last series is analyzed to determine the noise content. Using this information, it was possible to realistically estimate the errors associated with the station parameters.

In summary, the above procedure provided the velocity vector of each GPS station (described by the north, east and vertical components) and the related uncertainty.

\subsection{Horizontal Velocity Field}

The vector sum of the north and east velocity components gives the site absolute horizontal velocity. However, it is suitable for seismotectonic analysis subtracting the motion of the Eurasian plate from absolute velocity components. Therefore, I have used the plate rotation parameters provided by [151] to remove the Eurasia plate motion at each station. The residual velocity field (with respect to the Eurasian plate) is shown in Figure 5. This kinematic pattern updates previous results, based on a shorter observation time interval [140] [144] [155]. Indeed, this work use GPS measurements gathered in the last two decades (from 01/01/2001 to 30/04/2019).

The horizontal velocity field here presented confirms previous results [140] [155]. The GPS stations located on the Adriatic side of the Apennine belt show the highest horizontal velocity, with NNE-trending vectors reaching $6 \mathrm{~mm} /$ year (Figure 5). In the study area (included in the red box shown in Figure 5), the horizontal velocity clearly changes from the Adriatic to Tyrrhenian side. In the latter zone, including Tuscany, vectors are mostly NE-directed with modest amplitude ( $<3 \mathrm{~mm} /$ year). The divergence of horizontal velocity vectors between the Adriatic and Tyrrhenian sides implies active extension in the northern and central Apennines, as discussed in detail by [140] [155]. However, the study area needs an accurate reconstruction of the horizontal strain field, as described in the next paragraph.

\subsection{Horizontal Strain Field}

The theory of small deformations allows us calculating the horizontal strain rate from the geodetic velocity field. For this work, I used the interpolation method developed by [140] [155].

First, I superimposed a regular grid to the GPS network. By using the GPS horizontal velocity vectors (Figure 5), a weighted least square method provided six kinematic parameters for each point of the grid: 2 velocity components and 4 velocity gradients [156]. Then, the 4 components of the horizontal strain rate tensor (and the related eigenvectors) were computed from the velocity gradients [157].

The weight factors entering in the interpolation method depend on both the 
uncertainty affecting the horizontal velocity components and proximity between grid points and the GPS sites. To attribute a larger weight to the stations closest to a given grid points, the weight factors are estimated by multiplying the variance of the velocity components by the exponential factor $\mathrm{e}^{-d_{i j} / D}$ where $d_{i j}$ is the distance between the $\mathrm{i}$-th grid point and the $\mathrm{j}$-th GPS site, whereas D is the so-called attenuation distance [140] [157]. To improve the reliability of the results, I imposed two further geometric constraints [158] [159]: 1) the interpolated values are acceptable only if at least 3 GPS sites are located at a distance $\leq D$ from the grid point 2) such GPS sites must be evenly distributed in the region surrounding the grid point (at least one for each $120^{\circ}$ angular sector). If both these conditions are not met, the strain rate estimate is discarded.

Figure 6 shows the strain rate field obtained by using a $0.1^{\circ}$ Latitude $\times 0.1^{\circ}$ Longitude regular grid. The adopted attenuation distance is $\mathrm{D}=50 \mathrm{~km}$, about twice the average distance between the GPS stations shown in Figure 5 [140] [155].

The amplitude of the principal strain rate axes varies in the range $10^{-8}-10^{-7}$ $\mathrm{yr}^{-1}$ (Figure 6). Such values are lower than those observed at most active plate margins $\left(>10^{-7} \mathrm{yr}^{-1}\right)$. However, the study area deforms more rapidly than the adjacent foreland areas, such as the European continent north of the Alps, where the strain rate is much lower $\left(10^{-10}-10^{-9} \mathrm{yr}^{-1}[160]\right)$. Values of the geodetic strain rate comparable to those shown in Figure 5 are reported by [146] for the central and southern Apennines.

In the study area, the horizontal lengthening axis always has a NE-SW direction. Consequently, the shortening axis is directed NW-SE (Figure 6). However, one can note important changes in the relative amplitude of the two eigenvectors. Along the Tuscan-Emilian-Romagna Apennine arc, lengthening is much larger than shortening, implying a pure (up to radial) extensional strain style (see box a in Figure 6). Instead, moving towards the Tyrrhenian coast the amplitude of the two axes becomes nearly equal. This highlights a strike-slip strain style (see box b in Figure 6). Furthermore, strain rate amplitude clearly decreases from the Apennine watershed to the Tyrrhenian coast (Figure 6).

The geodetic strain field is broadly consistent with the strain style highlighted by ESMs (Figure 4). Indeed, shallow earthquakes along the Apennine arc (sectors I and II of Figure 4) show an extensional mechanism. On the other hand, most events occurred within inner Tuscany (sector III of Figure 4) have strike-slip mechanisms. Moreover, the direction of the seismological $\mathrm{T}$ and $\mathrm{P}$ axes is compatible with the principal axis of the geodetic strain rate tensor (Figure 4 and Figure 6).

The zone represented in Figure 6 is larger than the study area. To the north, the figure shows the Po Valley zone affected by the May, 2012 seismic sequence. In this area the geodetic strain is dominated by N-S compression (see box $\mathrm{c}$ in Figure 6), in good agreement with the EMSs of the 2012 seismic events [3]. This agreement corroborates the close relationships between seismic and geodetic strain, even outside the study area. 


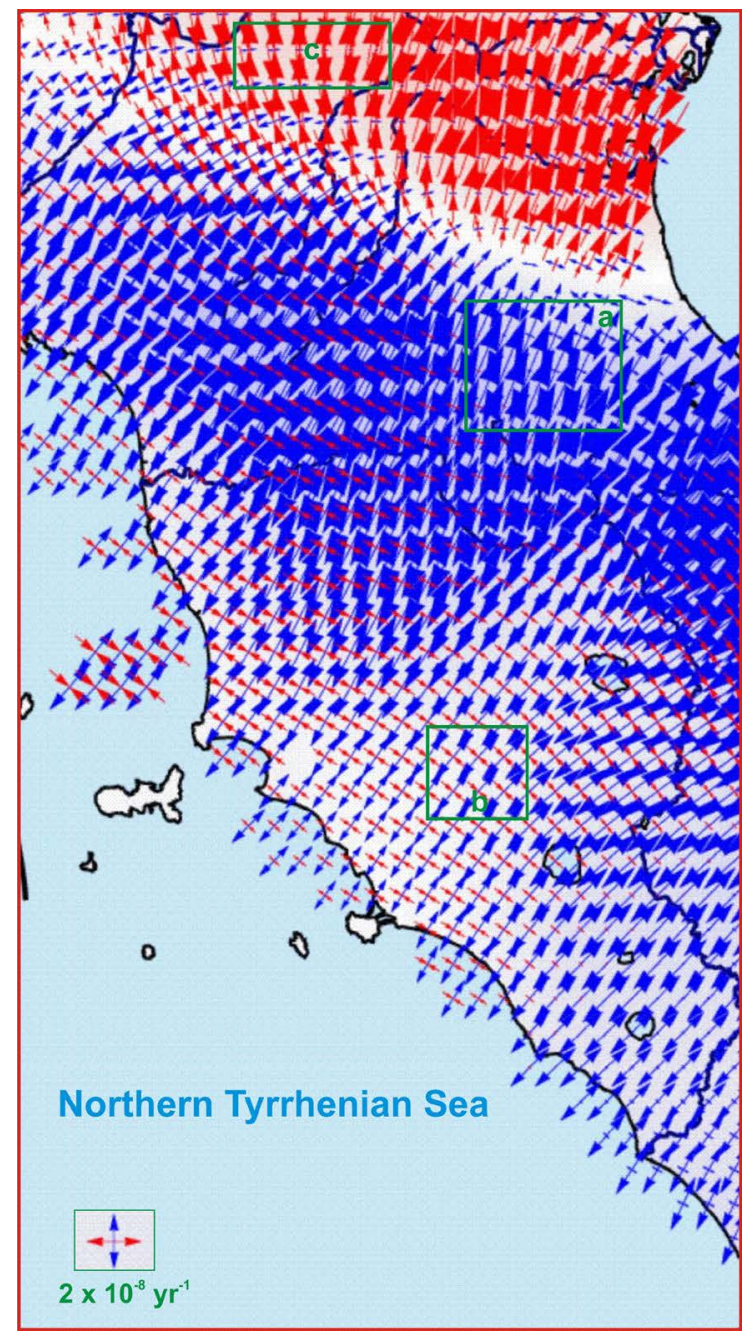

Figure 6. Horizontal strain rate field, derived from the velocity field shown in Figure 5 by the procedure described in the text (see also [140] [155]). The zone is contained in the box shown in Figure 5. The principal axes of strain rate tensor are calculated on a $0.1^{\circ} \times$ $0.1^{\circ}$ regular grid, with attenuation distance $\mathrm{D}=50 \mathrm{Km}$, i.e. roughly twice the average distance between the GPS stations shown in Figure 5 (see text). Converging red arrows indicate the principal shortening axis, while diverging blue arrows indicate the principal lengthening axis. The amplitude scale (expressed in $10^{-8}$ year $^{-1}$ or $3.17 \times 10^{-16} \mathrm{~s}^{-1}$ ) is shown at the bottom left. Boxes $\mathrm{a}, \mathrm{b}$ and $\mathrm{c}$ are mentioned in the text.

\section{Discussion}

The similarity of the seismic and geodetic strain fields suggests what strain regime affects the study area. Such regime refers to a short time interval (the last 10 - 20 years), so it cannot be extrapolated easily to past tectonic phases. However, the above results are relevant for the identification of seismogenic processes which take place in the study area.

First, seismic and geodetic strain can be used to evaluate the reliability of the active faults proposed in the literature. Along the Tuscan-Emilian-Romagna Apennine arc, the alleged active faults agree with the ESMs in two cases only. In north-western Tuscany, the Northern Apuan Alps Fault (NA in Figure 2; [86] is 
roughly compatible with the mechanism of the 21/06/2013 earthquake $\left(\mathrm{M}_{\mathrm{W}}=\right.$ 5.09) and of its aftershocks (Figure 4). In the Mugello basin, the Ronta and Sieve normal faults (Ro and Sv in Figure 2 [49]) seem to be compatible with the mechanism of the 09/12/2019 earthquake $\left(\mathrm{M}_{\mathrm{W}}=4.54\right)$. However, for both cases the absence of coseismic faulting precludes a definitive confirmation of this hypothesis.

On the other hand, the suggested trans-pressional [49] or compressional [70] active deformation along the Tuscan-Emilian-Romagna Apennine watershed is denied by the extensional ESMs and geodetic strain (Figure 4 and Figure 6).

For inner Tuscany, both seismic activity and geodetic data show a roughly strike-slip strain style. This casts doubt on the present activity of the normal fault shown in Figure 2, some of which are considered as seismogenic by [63]. Much less plausible is the present activity of the compressive tectonic features shown in Figure 3. More complex is the evaluation of the activity of the strike-slip faults reported in central Tuscany (Am, Ar, Ca, Rp, St and Vi in Figure 2). Their recent age, constrained by travertine dating [53] [57], and the strike-slip kinematics would suggest their present activity. However, the kinematics of these faults is still debated [56] [63]. Furthermore, recent earthquakes (from n.31 to $\mathrm{n} .41$ in Figure 4) are located quite far from the aforementioned faults.

The results provided by this work may also serve as constraints for a coherent model of the current deformation of the Apennine belt. [161] suggest that the central and northern Apennines are affected by an overall strike-slip stress regime, with sub-horizontal NW-SE $\sigma_{1}$ and NE-SW $\sigma_{3}$ axes. This stress regime would explain the main features of seismic activity recognized by [131]. [162] [163] [164] propose an evolutionary model for the northern Apennines, based on a belt-parallel compression. This model may explain several geological and geomorphological features observed in the study area, as the Quaternary uplift and intense volcanism (Section 2). Furthermore, both extensional strain along the northern Apennine arc and strike-slip strain in the inner Tuscany are compatible with the above model [162] [163] [164].

\section{Conclusion}

The source mechanism of small earthquakes $\left(\mathrm{M}_{\mathrm{W}}<5\right)$ helps to shed light on the active deformation of a given tectonic zone. However, in a limited time window ( $<10$ years) the number of recorded ESMs can be modest (a few dozen). Under these conditions, and in the absence of strong earthquakes $\left(M_{W}>5.5\right)$, it is not easy to evaluate to what extent source mechanisms represent the actual crustal deformation. This uncertainty is considerably attenuated by using independent pieces of evidence, such as the satellite geodesy measurements. The results of this work indicate that the information provided by the micro-seismicity is reliable, as it broadly agrees with the geodetic evidence. In zones characterized by low strain rate, where strong earthquakes may be rare, I therefore suggest to 
jointly use micro-seismic and geodetic data in order to reliably constrain the active deformation regime.

\section{Acknowledgements}

This work has been supported by the Italian Regione Toscana (Settore Sismica). The author would like to thank Dr. Nicola Cenni (University of Padova, Italy) for analysis of geodetic measurements. The numerous institutions that have kindly made available the GPS measurements are carefully listed by [140] [141] [144]. Figure 4, Figure 5 and Figure 6 have been elaborated with the Generic Mapping Tools [165]. Constructive comments provided by an anonymous reviewer helped improving the manuscript.

\section{Conflicts of Interest}

The author declares no conflicts of interest regarding the publication of this paper.

\section{References}

[1] Chiaraluce, L., Valoroso, L., Piccinini, D., Di Stefano, R. and De Gori, P. (2011) The Anatomy of the 2009 l'Aquila Normal Fault System (Central Italy) Imaged by High Resolution Foreshock and Aftershock Locations. Journal of Geophysical Research, 116. https://doi.org/10.1029/2011JB008352

[2] Chiaraluce, L., Di Stefano, R., Tinti, E., Scognamiglio, L., Michele, M., Casarotti, E., et al. (2017) The 2016 Central Italy Seismic Sequence: A First Look at the Mainshocks, Aftershocks, and Source Models. Seismological Research Letters, 88, 757-771. https://doi.org/10.1785/0220160221

[3] Govoni, A., Marchetti, A., De Gori, P., Di Bona, M., Lucente, F.P., Improta, L., Chiarabba, C., Nardi, A., Margheriti, L., Piana Agostinetti, N., Di Giovambattista, R., Latorre, D., Anselmi, M., Ciaccio, M.G., Moretti, M., Castellano, C. and Piccinini, D. (2014) The 2012 Emilia Seismic Sequence (Northern Italy): Imaging the Thrust Fault System by Accurate Aftershock Location. Tectonophysics, 622, 44-55. https://doi.org/10.1016/j.tecto.2014.02.013

[4] Cheloni, D., de Novellis, V., Albano, M., Antonioli, A., Anzidei, M., Atzori, S., et al. (2017) Geodetic Model of the 2016 Central Italy Earthquake Sequence Inferred from InSAR and GPS Data. Geophysical Research Letters, 44, 6778-6787. https://doi.org/10.1002/2017GL073580

[5] Scognamiglio, L., Tinti, E., Casarotti, E., Pucci, S., Villani, F., Cocco, M., et al. (2018) Complex Fault Geometry and Rupture Dynamics of the $\mathrm{M}_{\mathrm{w}} 6.5,30$ October 2016, Central Italy Earthquake. Journal of Geophysical Research Solid Earth, 123, 2943-2964. https://doi.org/10.1002/2018JB015603

[6] Rovida, A., Locati, M., Camassi, R., Lolli, B. and Gasperini, P. (2016) CPTI15, the 2015 Version of the Parametric Catalogue of Italian Earthquakes. Istituto Nazionale di Geofisica e Vulcanologia.

[7] Ripepe, M., Lacanna, G., Deguy, P., De Stefano, M., Mariani V. and Tanganelli, M. (2014) Large-Scale Seismic Vulnerability Assessment Method for Urban Centres. An Application to the City of Florence. Key Engineering Materials, 628, 49-54. https://doi.org/10.4028/www.scientific.net/KEM.628.49

[8] Brogi, A. (2011) Bowl-Shaped Basin Related to Low-Angle Detachment during 
Continental Extension: The Case of the Controversial Neogene Siena Basin (Central Italy, Northern Apennines). Tectonophysics, 499, 54-76. https://doi.org/10.1016/j.tecto.2010.12.005

[9] Bonini, M., Sani, F., Stucchi, E.M., Moratti, G., Benvenuti, M., Menanno, G. and Tanini, C. (2014) Late Miocene Shortening of the Northern Apennines Back-Arc. Journal of Geodynamics, 74, 1-31. https://doi.org/10.1016/j.jog.2013.11.002

[10] Sartori, R. and Capozzi, R. (1998) Patterns of Neogene to Recent Rift-Related Subsidence in the Tyrrhenian Domain. In: Cloething, S., Ranalli, G. and Ricci, C.A., Eds., Sedimentary Basins: Models and Constraints, International School "Earth and Planetary Sciences", Certosa di Pontignano (Siena), 147-158.

[11] Viti, M., Mantovani, E., Tamburelli, C. and Babbucci, D. (2009) Generation of Trench-Arc-Back Arc Systems in the Western Mediterranean Region Driven by Plate Convergence. Bollettino della Società Geologica Italiana, 128, 89-106.

[12] Bartole, R. (1995) The North Tyrrhenian-Northern Apennines Post Collisional System: Constraints for a Geodynamical Model. Terra Nova, 7, 7-30. https://doi.org/10.1111/j.1365-3121.1995.tb00664.x

[13] Pascucci, V., Martini, I.P., Sagri, M. and Sandrelli, F. (2007) Effects of Transverse Structural Lineaments on the Neogene-Quaternary Basins of Tuscany (Inner Northern Apennines, Italy). In: Nichols, G., Williams, E. and Paola, C., Eds., Sedimentary Processes, Environments and Basins: A Tribute to Peter Fried, International Association of Sedimentology, Special Publication 38, 155-182. https://doi.org/10.1002/9781444304411.ch8

[14] Molli, G. (2008) Northern Apennine-Corsica Orogenic System: An Updated Overview. Geological Society of London Special Publications, 298, 413-442. https://doi.org/10.1144/SP298.19

[15] Peccerillo, A. (2005) Plio-Quaternary Volcanism in Italy. Petrology, Geochemistry, Geodynamics. Springer-Verlag, Berlin-Heidelberg, Germany.

[16] Mele, G. and Sandvol, E. (2003) Deep Crustal Roots Beneath the Northern Apennines Inferred from Teleseismic Receiver Functions. Earth Planetary Science Letters, 211, 69-78. https://doi.org/10.1016/S0012-821X(03)00185-7

[17] Ponziani, F., De Franco, R. Minelli, G., Biella, G., Federico, C. and Pialli, G. (1995) Crustal Shortening and Duplication of the Moho in the Northern Apennines: A View from Seismic Refraction Data. Tectonophysics, 252, 391-418. https://doi.org/10.1016/0040-1951(95)00093-3

[18] Barchi, M., Minelli, G. and Pialli, G. (1998) The CROP03 Profile: A Synthesis of Results on Deep Structures of the Northern Apennines. Memorie della Società Geologica Italiana, 52, 383-400.

[19] Decandia, F.A., Lazzarotto, A., Liotta, D., Cernobori, L. and Nicolich, R. (1998) The CROP03 Traverse: Insights on Post-Collisional Evolution of Northern Apennines. Memorie della Società Geologica Italiana, 52, 427-439.

[20] Finetti, I.R., Boccaletti, M., Bonini, M., Del Ben, A., Geletti, R., Pipan, M. and Sani, F. (2001) Crustal Section Based on CROP Seismic Data Across the North Tyrrhenian-Northern Apennines-Adriatic Sea. Tectonophysics, 343, 135-163.

https://doi.org/10.1016/S0040-1951(01)00141-X

[21] Finetti, I.R., Boccaletti, M. Bonini, M., Del Ben, A., Pipan, M., Prizzon, A. and Sani, F. (2005) Lithospheric Tectono Stratigraphic Setting of the Ligurian Sea-Northern Apennines-Adriatic Foreland from Integrated CROP Seismic Data. In: Finetti, I.R., Ed., Deep Seismic Exploration of the Central Mediterranean and Italy, CROP PROJECT, Chapter 8, Elsevier, The Netherlands, 119-158. 
[22] Boccaletti, M, and Sani, F. (1998) Cover Thrust Reactivations Related to Internal Basement Involvement during Neogene-Quaternary Evolution of the Northern Apennines. Tectonics, 17, 112-130. https://doi.org/10.1029/97TC02067

[23] Boccaletti, M., Calamita, F., Deiana, G., Gelati, R., Massari, F., Moratti, G. and Ricci Lucchi, F. (1990) Migrating Foredeep Thrust Belt System in the Northern Apennine and Southern Alps. Palaeogeography, Palaeoclimatology, Palaeoecology, 77, 3-14. https://doi.org/10.1016/0031-0182(90)90095-O

[24] Di Giulio, A., Mancin, N., Martelli, L. and Sani, F. (2013) Foredeep Paleobathymetry and Subsidence Trends during Advancing Then Retreating Subduction: The Northern Apennine Case (Oligocene-Miocene, Italy). Basin Research, 24, 260-284. https://doi.org/10.1111/bre.12002

[25] Mauffret, A., Contrucci, I. and Brunet, C. (1999) Structural Evolution of the Northern Tyrrhenian Sea from New Seismic Data. Marine and Petroleum Geology, 16, 381-407. https://doi.org/10.1016/S0264-8172(99)00004-5

[26] Elter, P., Giglia, G., Tongiorgi, M. and Trevisan, L. (1975) Tensional and Compressional Areas in the Recent (Tortonian to Present) Evolution of the Northern Apennines. Bollettino di Geofisica Teorica ed Applicata, 17, 3-18.

[27] Martini, I.P. and Sagri, M. (1993) Tectono-Sedimentary Characteristics of Late Miocene Quaternary Extensional Basins of the Northern Apennines, Italy. Earth-Science Reviews, 34, 197-133. https://doi.org/10.1016/0012-8252(93)90034-5

[28] Bossio, A., Costantini, A., Foresi, L.M., Lazzarotto, A., Mazzanti, R., Mazzei, R., Pascucci, V., Salvatorini, G., Sandrelli, F. and Terzuoli, A. (1998) Neogene-Quaternary Sedimentary Evolution in the Western Side of the Northern Apennines (Italy). Memorie della Società Geologica Italiana, 52, 513-525.

[29] Cantini, P., Testa, G., Zanchetta, G. and Cavallini, R. (2001) The Plio-Pleistocene Evolution of Extensional Tectonics in Northern Tuscany, as Constrained by New Gravimetric Data from the Montecarlo Basin (Lower Arno Valley, Italy). Tectonophysics, 330, 25-43. https://doi.org/10.1016/S0040-1951(00)00217-1

[30] Decandia, F.A., Lazzarotto, A. and Liotta, D. (2001) Structural Features of Southern Tuscany, Italy. Ofioliti, 26, 287-300.

[31] Briganti, R., Ciufegni, A., Coli, M., Polimeni, S. and Pranzini, G. (2003) Underground Florence: Plio-Quaternary Geological Evolution of the Florence Area. Bollettino della Società Geologica Italiana, 12, 435-445.

[32] Brogi, A., Lazzarotto, A., Liotta, D., Ranalli, G. and CROP18 Working Group (2005) Crustal Structures in the Geothermal Areas of Southern Tuscany (Italy): Insights from the CROP 18 Deep Seismic Reflection Lines. Journal of Volcanology and Geothermal Research, 148, 60-80. https://doi.org/10.1016/j.jvolgeores.2005.03.014

[33] Brogi, A., Liotta, D., Meccheri, M. and Fabbrini, L. (2010) Transtensional Shear Zones Controlling Volcanic Eruptions: The Middle Pleistocene Mt Amiata Volcano (Inner Northern Apennines, Italy). Terra Nova, 22, 137-146. https://doi.org/10.1111/j.1365-3121.2010.00927.x

[34] Pascucci, V., Costantini, A., Martini, I.P. and Dringoli, R. (2006) Tectono-Sedimentary Analysis of a Complex, Extensional, Neogene Basin Formed on Thrust-Faulted, Northern Apennines Hinterland: Radicofani Basin, Italy. Sedimentary Geology, 183, 81-97. https://doi.org/10.1016/j.sedgeo.2005.09.009

[35] Brogi, A. (2008) The Structure of the Monte Amiata Volcano-Geothermal Area (Northern Apennines, Italy): Neogene-Quaternary Compression versus Extension. International Journal of Earth Sciences, 97, 677-703.

https://doi.org/10.1007/s00531-007-0191-1 
[36] Brogi, A. and Liotta, D. (2008) Highly Extended Terrains, Lateral Segmentation of the Substratum, and Basin Development: The Middle-Late Miocene Radicondoli Basin (Inner Northern Apennines, Italy). Tectonics, 27, TC5002. https://doi.org/10.1029/2007TC002188

[37] Pandeli, E., Bartolini, C., Dini, A. and Antolini, E. (2010) New Data on the Paleogeography of Southern Tuscany (Italy) Since Late Miocene Time. International Journal of Earth Sciences, 99, 1357-1381. https://doi.org/10.1007/s00531-009-0463-Z

[38] Brogi, A., Fidolini, F. and Liotta, D. (2013) Tectonic and Sedimentary Evolution of the Upper Valdarno Basin: New Insights from the Lacustrine S. Barbara Basin. Italian Journal of Geosciences (Bollettino della Società Geologica Italiana), 132, 81-97.

[39] Compagnoni, B. and Galluzzo, F., Coordinators (2004) Geological Map of Italy 1:1250000 Scale. The 32nd International Geological Congress, SELCA, Florence, 20-28 August 2004

https://www.isprambiente.gov.it/images/progetti/progetto-1250-ita.jpg

[40] Moratti, G. and Bonini, M. (1998) Structural Development of the Neogene Radicondoli-Volterra and Adjoining Hinterland Basins in Western Tuscany (Northern Apennines, Italy). Geological Journal, 33, 223-241.

https://doi.org/10.1002/(SICI)1099-1034(199810/12)33:4<223::AID-GJ799>3.0.CO; $\underline{2-\mathrm{E}}$

[41] Boccaletti, M., Bonini, M., Moratti, G. and Sani, F. (1999) Compressive Neogene-Quaternary Tectonics in the Hinterland Area of the Northern Apennines. Journal of Petroleum Geology, 22, 37-60. https://doi.org/10.1111/j.1747-5457.1999.tb00458.x

[42] Bonini, M. (1999) Basement-Controlled Neogene Polyphase Cover Thrusting and Basin Development along the Chianti Mountains Ridge (Northern Apennines, Italy). Geological Magazine, 136, 133-152. https://doi.org/10.1017/S0016756899002277

[43] Bonini, M., Moratti, G. and Sani, F. (1999) Evolution and Depocentre Migration in Thrust-Top Basins: Inferences from the Messinian Velona Basin (Northern Apennines, Italy). Tectonophysics, 304, 95-108. https://doi.org/10.1016/S0040-1951(98)00291-1

[44] Bonini, M. and Sani, F. (2002) Extension and Compression in the Northern Apennines (Italy) Hinterland: Evidence from the Late Miocene-Pliocene Siena-Radicofani Basin and Relations with Basement Structures. Tectonics, 21, 1-1-1-32.

https://doi.org/10.1029/2001TC900024

[45] Musumeci, G., Mazzarini, F., Corti, G., Barsella, M. and Montanari, D. (2005) Magma Emplacement in a Thrust Ramp Anticline: Field Data and Analogue Models. The Case of Gavorrano Granite (Northern Apennines, Italy). Tectonics, 24, TC6009. https://doi.org/10.1029/2005TC001801

[46] Musumeci, G., Mazzarini, F. and Barsella, M. (2008) Pliocene Crustal Shortening on the Tyrrhenian Side of the Northern Apennines: Evidence from the Gavorrano Antiform (Southern Tuscany, Italy). Journal of the Geological Society, 165, 105-114. https://doi.org/10.1144/0016-76492007-004

[47] Cerrina Feroni, A., Bonini, M., Martinelli, P., Moratti, G., Sani, F., Montanari, D. and Del Ventisette, C. (2006) Lithological Control on Thrust-Related Deformation in the Sassa-Guardistallo Basin (Northern Apennines Interland, Italy). Basin Research, 18, 301-321. https://doi.org/10.1111/j.1365-2117.2006.00295.x

[48] Bonini, M. and Tanini, C. (2009) Tectonics and Quaternary Evolution of the Northern Apennines Watershed Area (Upper Course of Arno and Tiber Rivers, Italy). Geological Journal, 44, 2-29. https://doi.org/10.1002/gj.1122 
[49] Sani, F., Bonini, M., Piccardi, L., Vannucci, G., Delle Donne, D., Benvenuti, M., Moratti, G., Corti, G., Montanari, D., Sedda, L. and Tanini, C. (2009) Late Pliocene-Quaternary Evolution of Outermost Hinterland Basins of the Northern Apennines (Italy), and Their Relevance to Active Tectonics. Tectonophysics, 476, 336-356. https://doi.org/10.1016/j.tecto.2008.12.012

[50] Sani, F., Bonini, M., Cerrina Feroni, A., Mazzarini, F., Moratti, G., Musumeci, G., Corti, G., Iatta, F. and Ellero, A. (2009) Messinian-Early Pliocene Crustal Shortening Along the Tyrrhenian Margin of Tuscany, Italy. Italian Journal of Geosciences (Bollettino della Società Geologica Italiana), 128, 593-604.

[51] Benvenuti, M., Del Conte, S., Scarselli, N. and Dominici, S. (2014) Hinterland Basin Development and Infilling through Tectonic and Eustatic Processes: Latest Messinian-Gelasian Valdelsa Basin, Northern Apennines, Italy. Basin Research, 26, 387-402. https://doi.org/10.1111/bre.12031

[52] Sani, F., Bonini, M., Montanari, D., Moratti, G., Corti, G. and Del Ventisette, C. (2016) The Structural Evolution of the Radicondoli-Volterra Basin (Southern Tuscany, Italy): Relationships with Magmatism and Geothermal Implications. Geothermics, 59, 38-55. https://doi.org/10.1016/j.geothermics.2015.10.008

[53] Brogi, A., Capezzuoli, E., Buracchi, E. and Branca, M. (2012) Tectonic Control on Travertine and Calcareous Tufa Deposition in a Low-Temperature Geothermal System (Sarteano, Central Italy). Journal of the Geological Society, 169, 461-476. https://doi.org/10.1144/0016-76492011-137

[54] Sorgi, C., Deffontaines, B., Hippolyte, J.C. and Cadet, J.P. (1998) An Integrated Analysis of Transverse Structures in the Northern Apennines, Italy. Geomorphology, 25, 193-206. https://doi.org/10.1016/S0169-555X(98)00041-5

[55] Bonini, M. (2009) Structural Controls on a Carbon Dioxide-Driven Mud Volcano Field in the Northern Apennines (Pieve Santo Stefano, Italy): Relations with Pre-Existing Steep Discontinuities and Seismicity. Journal of Structural Geology, 31, 44-54. https://doi.org/10.1016/j.jsg.2008.10.003

[56] Brogi, A. and Fabbrini, L. (2009) Extensional and Strike-Slip Tectonics across the Monte Amiata-Monte Cetona Transect (Northern Apennines, Italy) and Seismotectonic Implications. Tectonophysics, 476, 195-209.

https://doi.org/10.1016/j.tecto.2009.02.020

[57] Brogi, A., Capezzuoli, E., Aquè, R., Branca, M. and Voltaggio, M. (2010) Studying Travertines for Neotectonics Investigations: Middle-Late Pleistocene Syn-Tectonic Travertine Deposition at Serre di Rapolano (Northern Apennines, Italy). International Journal of Earth Sciences, 99, 1383-1398.

https://doi.org/10.1007/s00531-009-0456-y

[58] Brogi, A., Capezzuoli, E., Martini, I., Picozzi, M. and Sandrelli, F. (2014) Late Quaternary Tectonics in the Inner Northern Apennines (Siena Basin, Southern Tuscany, Italy) and Their Seismotectonic Implication. Journal of Geodynamics, 76, 25-45. https://doi.org/10.1016/j.jog.2014.03.001

[59] Brogi, A. (2011) Variation in Fracture Patterns in Damage Zones Related to Strike-Slip Faults Interfering with Pre-Existing Fractures in Sandstone (Calcione Area, Southern Tuscany, Italy). Journal of Structural Geology, 33, 644-661. https://doi.org/10.1016/j.jsg.2010.12.008

[60] Bianchi, V., Ghinassi, M., Aldinucci, M., Boaga, J., Brogi, A. and Deiana, R. (2015) Tectonically Driven Deposition and Landscape Evolution within Upland Incised Valleys: Ambra Valley Fill, Pliocene-Pleistocene, Tuscany, Italy. Sedimentology, 62, 897-927. https://doi.org/10.1111/sed.12165 
[61] Liotta, D. and Brogi, A. (2020) Pliocene-Quaternary Fault Kinematics in the Larderello Geothermal Area (Italy): Insights for the Interpretation of the Present Stress Field. Geothermics, 83, Article ID: 101714. https://doi.org/10.1016/j.geothermics.2019.101714

[62] Acocella, V. and Funiciello, R. (2006) Transverse Systems along the Extensional Tyrrhenian Margin of Central Italy and Their Influence on Volcanism. Tectonics, 25, TC2003. https://doi.org/10.1029/2005TC001845

[63] Piccardi, L., Vittori, E., Blumetti, A.M., Comerci, V., Di Manna, P., Guerrieri, L., Baglione, M. and D'Intinosante, V. (2017) Mapping Capable Faulting Hazard in a Moderate-Seismicity, High Heat-Flow Environment: The Tuscia Province (Southern Tuscany-Northern, Italy). Quaternary International, 451, 11-36. https://doi.org/10.1016/j.quaint.2017.07.018

[64] Machette, M.N. (2000) Active, Capable, and Potentially Active Faults: A Paleoseismic Perspective. Journal of Geodynamics, 29, 387-392.

https://doi.org/10.1016/S0264-3707(99)00060-5

[65] Barberi, F., Buonasorte, G., Cioni, R., Fiordelisi, A., Foresi, L., Iaccarino, S., Laurenzi, M. A., Sbrana, A., Vernia, L. and Villa, I. M. (1994) Plio-Pleistocene Geological Evolution of the Geothermal Area of Tuscany and Latium. Memorie Descrittive della Carta Geologica d' Italia, 49, 77-134.

[66] Bossio, A., Costantini, A., Foresi, L.M., Lazzarotto, A., Mazzanti, R., Mazzei, R., Pascucci, V., Salvatorini, G., Sandrelli, F. and Terzuoli, A. (1998) Neogene-Quaternary Sedimentary Evolution in the Western Side of the Northern Apennines (Italy). Memorie della Società Geologica Italiana, 52, 513-525.

[67] Cerrina Feroni, A., Martelli, L., Martinelli, P., Ottria, G. and Sarti, G. (2001) The Romagna Apennines, Italy: An Eroded Duplex. Geological Journal, 36, 39-54. https://doi.org/10.1002/gj.874

[68] Argnani, A., Barbacini, G., Bernini, M., Camurri, F., Ghielmi, M., Papani, G., Rizzini, F., Rogledi, S. and Torelli, L. (2003) Gravity Tectonics Driven by Quaternary Uplift in the Northern Apennines: Insights from the La Spezia-Reggio Emilia Geo-Transect. Quaternary International, 101-102, 13-26. https://doi.org/10.1016/S1040-6182(02)00088-5

[69] Bartolini, C. (2003) When Did the Northern Apennine Become a Mountain Chain? Quaternary International, 101-102, 75-80. https://doi.org/10.1016/S1040-6182(02)00090-3

[70] Boccaletti, M., Corti, G. and Martelli, L. (2010) Recent and Active Tectonics of the External Zone of the Northern Apennines (Italy). International Journal of Earth Sciences, 100, 1331-1348. https://doi.org/10.1007/s00531-010-0545-y

[71] Nisi, M.F., Antonioli, F., Pra, G.D., Leoni, G. and Silenzi S. (2003) Coastal Deformation between the Versilia and the Garigliano Plains (Italy) Since the Last Interglacial Age. Journal of Quaternary Science, 18, 709-721.

https://doi.org/10.1002/jqs.803

[72] Coltorti, M., Firuzabadi, D. and Pieruccini, P. (2011) Geomorphological Map and Land Units at 1:200,000 Scale of the Siena Province (Southern Tuscany, Italy). Journal of Maps, 7, 536-551. https://doi.org/10.4113/jom.2011.1193

[73] Segall, P. (2010) Earthquake and Volcano Deformation. Princeton University Press, Princeton, NJ, 200-266. https://doi.org/10.1515/9781400833856

[74] Acocella, V. (2000) Space Accommodation by Roof Lifting during Pluton Emplacement at Amiata (Italy). Terra Nova, 12, 149-155. https://doi.org/10.1046/j.1365-3121.2000.00286.x 
[75] Finetti, I.R. (2006) Basic Regional Crustal Setting and Superimposed Local Pluton-Intrusion-Related Tectonics in the Larderello-M. Amiata Geothermal Province, from Integrated CROP Seismic Data. Bollettino della Società Geologica Italiana, 125, 117-146.

[76] Coltorti, M., Ravani, S. and Verrazzani, F. (2007) The Growth of the Chianti Ridge: Progressive Unconformities and Depositional Sequences in the S. Barbara Basin (Upper Valdarno, Italy). Il Quaternario, 20, 67-84.

[77] Coltorti, M., Pieruccini, P. and Rustioni, M. (2008) The Barga Basin (Tuscany): A Record of Plio-Pleistocene Mountain Building of the Northern Apennines, Italy. Quaternary International, 189, 56-70. https://doi.org/10.1016/j.quaint.2007.08.048

[78] Balestrieri, M.L., Bernet, M., Brandon, M.T., Picotti, V., Reiners, P. and Zattin, M. (2003) Pliocene and Pleistocene Exhumation and Uplift of Two Key Areas of the Northern Apennines. Quaternary International, 101-102, 67-73. https://doi.org/10.1016/S1040-6182(02)00089-7

[79] Michetti, A.M., Serva, L. and Vittori, E. (2000) ITHACA Italy Hazard from Capable Faults: a Database of Active Faults of the Italian Onshore Territory. CD-Rom and Explanatory Notes. ANPA, Rome, Italy.

[80] Basili, R., Valensise, G., Vannoli, P., Burrato, P., Fracassi, U., Mariano, S., Tiberti, M.M. and Boschi, E. (2008) The Database of Individual Seismogenic Sources (DISS), Version 3: Summarizing 20 Years of Researcho Italy's Earthquake Geology. Tectonophysics, 453, 20-43. https://doi.org/10.1016/j.tecto.2007.04.014

[81] Bartolini, C., Bernini, M., Carloni, G.C., Costantini, A., Federici, P.R., Gasperi, G., Lazzarotto, A., Marchetti, G., Mazzanti, R., Papani, G., Pranzini, G., Rau, A., Sandrelli, F., Vercesi, P.L., Castaldini, D. and Francavilla, F. (1983) Carta Neotettonica dell'Appennino Settentrionale. Note Illustrative. Bollettino della Società Geologica Italiana, 101, 523-549.

[82] Boccaletti, M., Corti, G., Gasperini, P., Piccardi, L., Vannucci, G. and Clemente, S. (2001) Active Tectonics and Seismic Zonation of the Urban Area of Florence, Italy. Pure and Applied Geophysics, 158, 2313-2332. https://doi.org/10.1007/PL00001172

[83] Galadini, F., Meletti, C. and Vittori, E. (2001) Major Active Faults in Italy: Available Surficial Data. Netherlands Journal of Geosciences, 80, 273-296.

https://doi.org/10.1017/S001677460002388X

[84] Delle Donne, D., Piccardi, L., Odum, J.K., Stephenson, W.J. and Williams, R.A. (2007) High Resolution Shallow Reflection Seismic Image and Surface Evidence of the Upper Tiber Basin Active Faults (Northern Apennines, Italy). Bollettino della Società Geologica Italiana, 126, 323-331.

[85] Brozzetti, F., Boncio, P., Lavecchia, G. and Pace, B. (2009) Present Activity and Seismogenetic Potential of a Low-Angle Normal Fault System (Città di Castello, Italy): Constraints from Surface Geology, Seismic Reflection Data and Seismicity. Tectonophysics, 463, 31-46. https://doi.org/10.1016/j.tecto.2008.09.023

[86] Di Naccio, D., Boncio, P., Brozzetti, F., Pazzaglia, F.J. and Lavecchia, G. (2013) Morphotectonic Analysis of the Lunigiana and Garfagnana (Northern Apennines, Italy): Implications for Active Normal Faulting. Geomorphology, 201, 293-311. https://doi.org/10.1016/j.geomorph.2013.07.003

[87] Benvenuti, M., Bonini, M., Moratti, G., Ricci, M. and Tanini, C. (2008) Tectonic and Climatic Controls on Historical Landscape Modifications: The Avulsion of the Lower Cecina River (Tuscany, Central Italy). Geomorphology, 100, 269-284. https://doi.org/10.1016/j.geomorph.2007.12.009

[88] Civico, R., Pucci, S., Villani, F., Pizzimenti, L., De Martini, P.M., Nappi, R. and The 
Open EMERGEO Working Group (2018) Surface Ruptures Following the 30 October 2016 Mw 6.5 Norcia Earthquake, Central Italy. Journal of Maps, 14, 151-160. https://doi.org/10.1080/17445647.2018.1441756

[89] Villani, F., Civico, R., Pucci, S., Pizzimenti, L., Nappi, R., De Martini, P.M. and The Open EMERGEO Working Group (2018). A Database of the Coseismic Effects Following the 30 October 2016 Norcia Earthquake in Central Italy. Scientific Data, 5, Article No. 180049. https://doi.org/10.1038/sdata.2018.49

[90] Villani, F., Pucci, S., Civico, R., De Martini, P.M., Cinti, F.R. and Pantosti, D. (2018) Surface Faulting of the 30 October $2016 \mathrm{Mw}$ 6.5 Central Italy Earthquake: Detailed Analysis of a Complex Coseismic Rupture. Tectonics, 37, 3378-3410. https://doi.org/10.1029/2018TC005175

[91] Caskey, S.J., Wesnousky, S.G., Zhang, P. and Slemmons, D.B. (1996) Surface Faulting of the 1954 Fairview Peak (MS 7.2) and Dixie Valley (MS 6.8) Earthquakes, Central Nevada. Bulletin of the Seismological Society of America, 86, 761-787.

[92] Meyer, B., Armijo, R., Massonnet, D., De Chabalier, J.B., Delacourt, C., Ruegg, J.C. and Papanastassiou, D. (1996) The 1995 Grevena (Northern Greece) Earthquake: Fault Model Constrained with Tectonic Observations and SAR Interferometry. Geophysical Research Letters, 23, 2677-2680. https://doi.org/10.1029/96GL02389

[93] Jacques, E., Kidane, T., Tapponnier, P., Manighetti, I., Gaudemer, Y., Meyer, B. and Armijo, R. (2011) Normal Faulting during the August 1989 Earthquakes in Central Afar: Sequential Triggering and Propagation of Rupture along the Dôbi Graben. Bulletin of the Seismological Society of America, 101, 994-1023. https://doi.org/10.1785/0120080317

[94] Vallage, A., Klinger, Y., Lacassin, R., Delorme, A. and Pierrot-Deseilligny, M. (2016) Geological Structures Control on Earthquake Ruptures: The $M_{w}$ 7.7, 2013, Balochistan Earthquake, Pakistan. Geophysical Research Letters, 43, 10155-10163. https://doi.org/10.1002/2016GL070418

[95] Klinger, Y., Okubo, K., Vallage, A., Champenois, J., Delorme, A., Rougier, E. and Baize, S. (2018) Earthquake Damage Patterns Resolve Complex Rupture Processes. Geophysical Research Letters, 45, 10279-10287. https://doi.org/10.1029/2018GL078842

[96] Sloan, D., Wells, D., Borchardt, G., Caulfield, J., Doolin, D.M., Eidinger, J., Gee, L.S., Graymer, R.W., Hellweg, P., Kropp, A., Lienkaemper, J., Rabamad, C., Sitar, N., Stenner, H., Tobriner, S., Tsztoo, D. and Zoback, M.L. (2006) The Hayward Fault. In: Prentice, C.S., Scotchmoor, J.G., Moores, E.M. and Kiland, J.P., Eds., GSA Field Guide 7: 1906 San Francisco Earthquake GSA Field Guides, The Geological Society of America, 273-331. https://doi.org/10.1130/2006.1906SF(17)

[97] Bilham, R., Ozener, H., Mencin, D., Dogru, A., Ergintav, S., Cakir, Z., Aytun, A. Aktug, B., Yilmaz, O., Johnson, W. and Mattioli, G. (2016) Surface Creep on the North Anatolian Fault at Ismetpasa, Turkey, 1944-2016. Journal of Geophysical Research Solid Earth, 121, 7409-7431. https://doi.org/10.1002/2016JB013394

[98] Harris, R.A. (2017) Large Earthquakes and Creeping Faults. Reviews of Geophysics, 55, 169-198. https://doi.org/10.1002/2016RG000539

[99] Cowan, D.S. (1999) Do Faults Preserve a Record of Seismic Slip? A Field Geologist's Opinion. Journal of Structural Geology, 21, 995-1001. https://doi.org/10.1016/S0191-8141(99)00046-2

[100] Rowe, C.D. and Griffith, W.A. (2015) Do Faults Preserve a Record of Seismic Slip: A Second Opinion. Journal of Structural Geology, 78, 1-26.

https://doi.org/10.1016/j.jsg.2015.06.006 
[101] Bullard, T.F. and Lettis, W.R. (1993) Quaternary Fold Deformation Associated with Blind Thrust Faulting, Los Angeles Basin, California. Journal of Geophysical Research, 98, 8349-8369. https://doi.org/10.1029/93/B00012

[102] Burrato, P., Ciucci F. and Valensise, G. (2003) An Inventory of River Anomalies in the Po Plain, Northern Italy: Evidence for Active Blind Thrust Faulting. Annals of Geophysics, 46, 865-882.

[103] Burrato, P., Vannoli, P., Fracassi, U., Basili, R. and Valensise, G. (2012) Is Blind Faulting Truly Invisible? Tectonic-Controlled Drainage Evolution in the Epicentral Area of the May 2012, Emilia-Romagna Earthquake Sequence (Northern Italy). Annals of Geophysics, 55, 525-531.

[104] Bull, W.B. (2007) Tectonic Geomorphology of Mountains: A New Approach to Paleoseismology. Blackwell Publishing Ltd., USA, UK, Australia.

[105] Pizzi, A. and Scisciani, V. (2012) The May 2012 Emilia (Italy) Earthquakes: Preliminary Interpretations on the Seismogenic Source and the Origin of the Coseismic Ground Effects. Annals of Geophysics, 55, 751-757.

[106] Bucci, F., Cardinali, M. and Guzzetti, F. (2013) Structural Geomorphology, Active Faulting and Slope Deformations in the Epicentre Area of the $M_{w} 7.0,1857$, Southern Italy Earthquake. Physics and Chemistry of the Earth, 63, 12-24. https://doi.org/10.1016/j.pce.2013.04.005

[107] Benedetti, L., Tapponier, P., King, G.C.P. and Piccardi, L. (1998) Surface Rupture of the 1857 Southern Italian Earthquake? Terra Nova, 10, 206-210.

https://doi.org/10.1046/j.1365-3121.1998.00189.x

[108] Bartolini, C. (2012) Is the Morphogenetic Role of Tectonics Overemphasized at Times? Bollettino di Geofisica Teorica ed Applicata, 53, 459-470.

[109] Mirabella, F., Ciaccio, M.G., Barchi, M.R. and Merlini, S. (2004) The Gubbio Fault (Central Italy): Geometry, Displacement Distribution and Tectonic Evolution. Journal of Structural Geology, 26, 2233-2249. https://doi.org/10.1016/j.jsg.2004.06.009

[110] Collettini, C., Barchi, M., Chiaraluce, L., Mirabella, F. and Pucci, S. (2003) The Gubbio Fault: Can Different Methods Give Pictures of the Same Object? Journal of Geodynamics, 36, 51-66. https://doi.org/10.1016/S0264-3707(03)00038-3

[111] Pucci, S., De Martini, P.M., Pantosti, D. and Valensise, G. (2003) Geomorphology of the Gubbio Basin (Central Italy): Understanding the Active Tectonics and Earthquake Potential. Annals of Geophysics, 46, 837-864.

[112] Hart, M.W., Shaller, P.J. and Farrand, G.T. (2012) When Landslides Are Misinterpreted as Faults: Case Studies from the Western United States. Environmental \& Engineering Geoscience, 18, 313-325. https://doi.org/10.2113/gseegeosci.18.4.313

[113] Fubelli, G., Gori, S., Falcucci, E., Galadini, F. and Messina, P. (2009) Geomorphic Signatures of Recent Normal Fault Activity versus Geological Evidence of Inactivity: Case Studies from the Central Apennines (Italy). Tectonophysics, 476, 252-268. https://doi.org/10.1016/j.tecto.2008.10.026

[114] Kayal, J.R. (2008) Microearthquake Seismology and Seismotectonics of South Asia. Co-published by Springer, Dordrecht, The Netherlands with Capital Publishing Company, New Delhi, India, 1-503.

[115] Aki, K. and Richard, P. (1980) Quantitative Seismology: Theory and Methods. Freeman, San Francisco, CA.

[116] Frohlich, C. and Apperson, D. (1992) Earthquake Focal Mechanisms, Moment Tensors, and the Consistency of the Seismic Activity Near Plate Boundaries. Tectonics, 11, 279-296. https://doi.org/10.1029/91TC02888 
[117] Maury, J., Cornet, F.H. and Dorbath, L. (2013) A Review of Methods for Determining Stress Fields from Earthquakes Focal Mechanisms; Application to the Sierentz 1980 Seismic Crisis (Upper Rhine Graben). Bulletin Societe Géologique de France, 184, 319-334.

[118] Kassaras, I.G. and Kapetanidis, V. (2018) Resolving the Tectonic Stress by the Inversion of Earthquake Focal Mechanisms. Application in the Region of Greece. A Tutorial. In: D’Amico, S. (Ed.), Moment Tensor Solutions, Springer Natural Hazards, Springer, Cham, 405-452. https://doi.org/10.1007/978-3-319-77359-9 19

[119] Scholz, C.H. and Cowie, P.A. (1990) Determination of Total Strain from Faulting Using Slip Measurements. Nature, 346, 837-839. https://doi.org/10.1038/346837a0

[120] Amelung, F. and King, G. (1997) Large-Scale Tectonic Deformation Inferred from Small Earthquakes. Nature, 386, 702-705. https://doi.org/10.1038/386702a0

[121] Marsan, D. (2005) The Role of Small Earthquakes in Redistributing Crustal Elastic Stress. Geophysical Journal International, 163, 141-151. https://doi.org/10.1111/j.1365-246X.2005.02700.x

[122] Console, R. and Rosini, R. (1998) Non-Double-Couple Microearthquakes in the Geothermal Field of Larderello, Central Italy. Tectonophysics, 289, 203-220. https://doi.org/10.1016/S0040-1951(97)00316-8

[123] Kravanja, S., Batini, F., Fiordelisi, A. and Panza, G.F. (2000) Full Moment Tensor Retrieval from Waveform Inversion in the Larderello Geothermal Area. Pure and Applied Geophysics, 157, 1379-1392. https://doi.org/10.1007/PL00001124

[124] Albarello, D., Batini, F., Bianciardi, P., Ciulli, B., Spinelli, E. and Viti, M. (2005) Stress Field Assessment from Ill-Defined Fault PlaneSolutions: An Example from the Larderello Geothermal Field (Western Tuscany, Italy). Bollettino della Societa Geologica Italiana, 3, 187-193.

[125] Eva, E., Ferretti, G. and Solarino, S. (2005) Superposition of Different Stress Orientations in the Western Sector of the Northern Apennines (Italy). Journal of Seismology, 9, 413-430. https://doi.org/10.1007/s10950-005-1419-9

[126] Eva, E., Solarino, S. and Boncio, P. (2014) HypoDD Relocated Seismicity in Northern Apennines (Italy) Preceding the 2013 Seismic Unrest: Seismotectonic Implications for the Lunigiana-Garfagnana Area. Bollettino di Geofisica Teorica ed Applicata, 55, 739-754.

[127] Piccinini, D., Piana Agostinetti, N., Roselli, P., Ibs-von Seht, M. and Braun, T. (2009) Analysis of Small Magnitude Seismic Sequences Along the Northern Apennines (Italy). Tectonophysics, 476, 136-144. https://doi.org/10.1016/j.tecto.2009.04.005

[128] Frepoli, A. and Amato, A. (2000) Spatial Variation in Stresses in Peninsular Italy and Sicily from Background Seismicity. Tectonophysics, 317, 109-124. https://doi.org/10.1016/S0040-1951(99)00265-6

[129] Gephart, J. and Forsyth, W. (1984) An Improved Method for Determining the Regional Stress Tensor Using Earthquake Focal Mechanism Data: Application to the San Fernando Earthquake Sequence. Journal of Geophysical Research, 89, 9305-9320. https://doi.org/10.1029/JB089iB11p09305

[130] Montone, P., Mariucci, M.T., Pondrelli, S. and Amato, A. (2004) An Improved Stress Map for Italy and Surrounding Regions (Central Mediterranean). Journal of Geophysical Research, 109, B10410. https://doi.org/10.1029/2003JB002703

[131] Elter, F.M., Elter, P., Eva, C., Eva, E., Kraus, R.K., Padovano, M. and Solarino, S. (2011) Strike-Slip Geometry Inferred from the Seismicity of the Northern-Central Apennines (Italy). Journal of Geodynamics, 52, 379-388. 
https://doi.org/10.1016/j.jog.2011.03.003

[132] Chiarabba, C., Covone, L. and Di Stefano, R. (2005) A New View of Italian Seismicity Using 20 Years of Instrumental Recordings. Tectonophysics, 395, 251-268. https://doi.org/10.1016/j.tecto.2004.09.013

[133] Scognamiglio, L., Tinti, E. and Quintiliani, M. (2006) Time Domain Moment Tensor [Data Set]. Istituto Nazionale di Geofisica e Vulcanologia (INGV).

[134] Krieger, L. and Heimann, S., (2012) MoPaD-Moment Tensor Plotting and Decomposition: A Tool for Graphical and Numerical Analysis of Seismic Moment Tensors. Seismological Research Letters, 83, 589-595. https://doi.org/10.1785/gssrl.83.3.589

[135] Vannucci, G. and Gasperini, P. (2004) The New Release of the Database of Earthquake Mechanisms of the Mediterranean Area (EMMA Version 2). Annals of Geophysics, 47, 303-327.

[136] Piccinini, D., Chiarabba, C., Augliera, P. and Monghidoro Earthquake Group (2006) Compression Along the Northern Apennines? Evidence from the $\mathrm{M}_{\mathrm{w}} 5.3$ Monghidoro Earthquake. Terra Nova, 18, 89-94.

https://doi.org/10.1111/j.1365-3121.2005.00667.x

[137] Argus, D.F., Gordon, R.G., Heflin, M.B., Ma, C., Eanes, R.J., Willis, P., Peltier, W.R. and Owen, S.E. (2010) The Angular Velocities of the Plates and the Velocity of Earth's Centre from Space Geodesy. Geophysical Journal International, 180, 913-960. https://doi.org/10.1111/j.1365-246X.2009.04463.x

[138] D’Agostino, N., Avallone, A., Cheloni, D., D’Anastasio, E., Mantenuto, S. and Selvaggi, G. (2008) Active Tectonics of the Adriatic Region from GPS and Earthquake Slip Vectors. Journal of Geophysical Research, 113, B12413. https://doi.org/10.1029/2008JB005860

[139] Devoti, R., Esposito, A., Pietrantonio, G., Pisani, A.R. and Riguzzi, F. (2011) Evidence of Large Scale Deformation Patterns from GPS Data in the Italian Subduction Boundary. Earth and Planetary Science Letters, 311, 230-241. https://doi.org/10.1016/j.epsl.2011.09.034

[140] Cenni, N., Mantovani, E., Baldi, P. and Viti, M. (2012) Present Kinematics of Central and Northern Italy from Continuous GPS Measurements. Journal of Geodynamics, 58, 62-72. https://doi.org/10.1016/j.jog.2012.02.004

[141] Cenni, N., Viti, M., Baldi, P., Mantovani, E., Bacchetti, M. and Vannucchi, A. (2013) Present Vertical Movements in Central and Northern Italy from GPS Data: Possible Role of Natural and Anthropogenic Causes. Journal of Geodynamics, 71, 74-85. https://doi.org/10.1016/j.jog.2013.07.004

[142] Serpelloni, E., Anzidei, M., Baldi, P., Casula, G. and Galvani, G. (2005) Crustal Velocity and Strain-Rate Fields in Italy and Surrounding Regions: New Results from the Analysis of Permanent and Non-Permanent GPS Networks. Geophysical Journal International, 161, 861-880. https://doi.org/10.1111/j.1365-246X.2005.02618.x

[143] D’Agostino, N., Mantenuto, S., D’Anastasio, E., Avallone, A., Barchi, M., Collettini, C., Radicioni, F., Stoppini, A. and Fastellini, G. (2009) Contemporary Crustal Extension in the Umbria-Marche Apennines from Regional CGPS Networks and Comparison between Geodetic and Seismic Deformation. Tectonophysics, 476, 3-12. https://doi.org/10.1016/j.tecto.2008.09.033

[144] Cenni, N., Viti, M. and Mantovani, E. (2015) Space Geodetic Data (GPS) and Earthquake Forecasting: Examples from the Italian Geodetic Network. Bollettino di Geofisica Teorica e Applicata, 56, 129-150.

[145] D’Agostino, N. (2014) Complete Seismic Release of Tectonic Strain and Earthquake 
Recurrence in the Apennines (Italy). Geophysical Research Letters, 41, 1155-1162. https://doi.org/10.1002/2014GL059230

[146] Rontogianni, S. (2010) Comparison of Geodetic and Seismic Strain Rates in Greece by Using a Uniform Processing Approach to Campaign GPS Measurements over the Interval 1994-2000. Journal of Geodynamics, 50, 381-399.

https://doi.org/10.1016/j.jog.2010.04.008

[147] Baldi, P., Casula, G., Cenni, N., Loddo, F. and Pesci, A. (2009) GPS-Based Monitoring of Land Subsidence in the Po Plain (Northern Italy). Earth and Planetary Science Letters, 288, 204-212. https://doi.org/10.1016/j.epsl.2009.09.023

[148] Herring, T.A., King, R.W., Floyd, M.A. and McClusky, S.C. (2018) GAMIT Reference Manual, GPS Analysis at MIT, Release 10.7. Department of Earth, Atmospheric and Planetary Sciences, Massachusetts Institute of Technology, Cambridge, MA.

[149] Herring, T.A., Floyd, M.A., King, R.W and McClusky, S.C. (2018) Global Kalman filter VLBI and GPS Analysis Program, GLOBK Reference Manual, Release 10.6. Department of Earth, Atmospheric and Planetary Sciences, Massachusetts Institute of Technology, Cambridge, MA.

[150] Dong, D., Herring, T.A. and King, R.W. (1998) Estimating Regional Deformation from a Combination of Space and Terrestrial Geodetic Data. Journal of Geodesy, 72, 200-214. https://doi.org/10.1007/s001900050161

[151] Altamimi, Z., Rebischung, P., Métivier, L. and Collilieux, X. (2016) ITRF2014: A New Release of the International Terrestrial Reference Frame Modeling Nonlinear Station Motions. Journal of Geophysical Research: Solid Earth, 121, 6109-6131. https://doi.org/10.1002/2016JB013098

[152] Bos, M.S., Fernandes, R.M.S., Williams, S.D.P. and Bastos, L. (2013) Fast Error Analysis of Continuous GNSS Observations with Missing Data. Journal of Geodesy, 87, 351-360. https://doi.org/10.1007/s00190-012-0605-0

[153] Lomb, N.R (1976) Least-Squares Frequency Analysis of Unevenly Spaced Data. Astrophysical and Space Science, 39, 447-462. https://doi.org/10.1007/BF00648343

[154] Scargle, J.D. (1982) Studies in Astronomical Time Series Analysis II. Statistical Aspects of Spectral Analysis of Unevenly Sampled Data. Astrophysical Journal, 263, 835-853. https://doi.org/10.1086/160554

[155] Mantovani, E., Viti, M., Cenni, N., Babbucci, D., Tamburelli, C., Baglione, M. and D'Intinosante, V. (2015) Seismotectonics and Present Seismic Hazard in the Tuscany-Romagna-Marche-Umbria Apennines (Italy). Journal of Geodynamics, 89, 1-14. https://doi.org/10.1016/j.jog.2015.05.001

[156] Feigl, K.L., King, R.W. and Jordan, T.H. (1990) Geodetic Measurement of Tectonic Deformation in the Santa Maria Fold and Thrust Belt, California. Journal of Geophysical Research, 95, 2679-2699. https://doi.org/10.1029/JB095iB03p02679

[157] Shen, Z.K., Jackson, D.D. and Ge, B.X. (1996) Crustal Deformation across and beyond the Los Angeles Basin from Geodetic Measurements. Journal of Geophysical Research, 101, 27957-27980. https://doi.org/10.1029/96JB02544

[158] Teza, G., Pesci, A. and Galgaro, A. (2008) Grid_Strain and Grid_Strain3: Software Packages for Strain Field Computation in 2D and 3D Environment. Computer \& Geosciences, 34, 1142-1153. https://doi.org/10.1016/j.cageo.2007.07.006

[159] Teza, G., Pesci, A. and Casula, G. (2012) Strain Rate Computation in Northern Victoria Land (Antarctica) from Episodic GPS Surveys. Geophysical Journal International, 189, 851-862. https://doi.org/10.1111/j.1365-246X.2012.05403.x

[160] Talwani, P. (1999) Fault Geometry and Earthquakes in Continental Interiors. Tec- 
tonophysics, 305, 371-379. https://doi.org/10.1016/S0040-1951(99)00024-4

[161] Elter, F.M., Elter, P., Eva, C., Eva, E., Kraus, R.K., Padovano, M. and Solarino, S. (2012) An Alternative Model for the Recent Evolution of Northern-Central Apennines (Italy). Journal of Geodynamics, 54, 55-63.

https://doi.org/10.1016/j.jog.2011.11.001

[162] Viti, M., Mantovani, E., Babbucci, D., Tamburelli, C., Cenni, N., Baglione, M. and D'Intinosante, V. (2015) Belt-Parallel Shortening in the Northern Apennines and Seismotectonic Implications. International Journal of Geosciences, 6, 938-961. https://doi.org/10.4236/ijg.2015.68075

[163] Mantovani, E., Viti, M., Babbucci, D., Tamburelli, C. and Cenni, N. (2019) How and Why the Present Tectonic Setting in the Apennine Belt Has Developed. Journal of the Geological Society of London, 176, 1291-1302.

https://doi.org/10.1144/jgs2018-175

[164] Mantovani, E., Viti, M., Babbucci, D., Tamburelli, C. and Cenni, N. (2020) Geodynamics of the Central-Western Mediterranean Region: Plausible and Non-Plausible Driving Forces. Marine and Petroleum Geology, 113, Article ID: 104121.

https://doi.org/10.1016/j.marpetgeo.2019.104121

[165] Wessel, P. and Smith, W.H.F. (1998) New, Improved Version of the Generic Mapping Tools Released. Eos Transactions American Geophysical Union, 79, 579. https://doi.org/10.1029/98EO00426

[166] Mckenzie, D.P. (1969) The Relation between Fault Plane Solution for Earthquakes and the Directions of the Principal Stresses. Bulletin of the Seismological Society of America, 59, 591-601.

[167] Wyss, M., Liang, B.Y., Tanigawa, W.R. and Wu, X.P. (1992) Comparison of Orientation of Stress and Strain Tensors Based on Fault Plane Solution in Kaoiki, Hawaii. Journal of Geophysical Research, 97, 4769-4790. https://doi.org/10.1029/91JB02968 


\section{Appendix}

The Appendix presents the seismic data used in this work. Figure A1 provides details about the earthquake source mechanisms shown in Figure 4, in particular the poles of $\mathrm{P}$ and $\mathrm{T}$ axes discussed in the text (Section 3). Table A1 shown the basic parameters of the earthquake focal mechanisms discussed in the text (Section 3 and Figure 4). Data have been taken from http://terremoti.ingv.it/tdmt.

Table A1. Parameters of the earthquake source mechanisms shown in Figure 4. From the left: event number, date, epicenter coordinates, hypocentre depth $(\mathrm{H})$, moment magnitude $\left(\mathrm{M}_{\mathrm{W}}\right)$, strike $(\phi)$, dip $(\delta)$ and rake $(\lambda)$ angles for the first and second nodal plane [115].

\begin{tabular}{|c|c|c|c|c|c|c|c|c|c|c|c|c|c|}
\hline $\mathrm{N}$ & Year & Month & Day & Lat $\left({ }^{\circ} \mathrm{N}\right)$ & Lon $\left({ }^{\circ} \mathrm{E}\right)$ & $\mathrm{H}(\mathrm{km})$ & $\mathrm{M}_{\mathrm{w}}$ & $\phi_{1}\left(^{\circ}\right)$ & $\delta_{1}\left(\left(^{\circ}\right)\right.$ & $\lambda_{1}\left(^{\circ}\right)$ & $\phi_{2}\left(^{\circ}\right)$ & $\delta_{2}\left(^{\circ}\right)$ & $\lambda_{2}\left(^{\circ}\right)$ \\
\hline 1 & 2016 & 06 & 23 & 44.1663 & 9.9105 & 12 & 3.73 & 254 & 85 & -161 & 162 & 71 & -5 \\
\hline 2 & 2013 & 06 & 21 & 44.1682 & 10.1198 & 8 & 3.68 & 310 & 62 & -78 & 105 & 31 & -78 \\
\hline 3 & 2013 & 06 & 21 & 44.1588 & 10.1483 & 6 & 4.01 & 296 & 70 & -70 & 70 & 28 & -132 \\
\hline 4 & 2013 & 06 & 21 & 44.1528 & 10.1350 & 5 & 5.09 & 107 & 49 & -64 & 251 & 47 & -116 \\
\hline 5 & 2013 & 01 & 25 & 44.1683 & 10.4543 & 18 & 4.82 & 237 & 82 & -165 & 145 & 76 & -8 \\
\hline 6 & 2013 & 06 & 21 & 44.1607 & 10.1585 & 7 & 3.65 & 238 & 72 & -124 & 123 & 38 & -31 \\
\hline 7 & 2013 & 06 & 21 & 44.1548 & 10.1437 & 5 & 3.56 & 117 & 59 & -53 & 242 & 47 & -135 \\
\hline 8 & 2013 & 06 & 23 & 44.1508 & 10.1857 & 4 & 3.54 & 213 & 61 & -140 & 101 & 55 & -35 \\
\hline 9 & 2013 & 06 & 23 & 44.1762 & 10.2108 & 6 & 4.40 & 238 & 58 & -116 & 101 & 41 & -55 \\
\hline 10 & 2013 & 06 & 29 & 44.1502 & 10.1743 & 5.3 & 3.34 & 249 & 48 & -114 & 103 & 47 & -65 \\
\hline 11 & 2013 & 06 & 30 & 44.1710 & 10.2047 & 5 & 4.54 & 256 & 50 & -105 & 99 & 42 & -73 \\
\hline 12 & 2013 & 06 & 30 & 44.1780 & 10.2073 & 5 & 3.56 & 239 & 59 & -122 & 109 & 43 & -49 \\
\hline 13 & 2013 & 07 & $/ 08$ & 44.1517 & 10.1815 & 2 & 3.38 & 252 & 53 & -106 & 97 & 40 & -71 \\
\hline 14 & 2013 & 08 & 14 & 44.1663 & 10.1952 & 5 & 3.52 & 237 & 61 & -124 & 111 & 44 & -45 \\
\hline 15 & 2014 & 09 & 25 & 44.1462 & 10.2243 & 6.82 & 3.17 & 241 & 70 & -134 & 131 & 47 & -28 \\
\hline 16 & 2013 & 10 & 19 & 43.6745 & 10.2737 & 5 & 3.49 & 112 & 58 & -139 & 357 & 56 & -40 \\
\hline 17 & 2018 & 07 & 01 & 44.2003 & 10.5590 & 14.2 & 3.57 & 281 & 47 & -94 & 107 & 44 & -85 \\
\hline 18 & 2014 & 09 & 07 & 44.1270 & 10.6770 & 15 & 4.06 & 339 & 69 & -41 & 86 & 52 & -152 \\
\hline 19 & 2015 & 04 & 16 & 44.1588 & 10.9057 & 13 & 3.30 & 180 & 86 & -39 & 273 & 51 & -175 \\
\hline 20 & 2015 & 07 & 22 & 44.1608 & 10.8888 & 11 & 3.67 & 346 & 75 & -44 & 89 & 48 & -160 \\
\hline 21 & 2013 & 06 & 14 & 44.2728 & 11.0377 & 24 & 3.74 & 80 & 60 & 97 & 246 & 31 & 78 \\
\hline 22 & 2015 & 01 & 23 & 44.1293 & 11.1357 & 6 & 4.26 & 127 & 60 & -88 & 304 & 30 & -93 \\
\hline 23 & 2015 & 01 & 23 & 44.1362 & 11.1492 & 10 & 3.69 & 122 & 49 & -79 & 286 & 43 & -102 \\
\hline 24 & 2015 & 02 & 17 & 44.1673 & 11.4068 & 7 & 3.73 & 130 & 68 & -59 & 252 & 37 & -142 \\
\hline 25 & 2019 & 12 & 09 & 43.9955 & 11.3137 & 6 & 4.54 & 105 & 46 & -106 & 308 & 46 & -74 \\
\hline 26 & 2018 & 05 & 03 & 44.0582 & 11.7222 & 6.4 & 3.37 & 102 & 51 & -95 & 290 & 39 & -84 \\
\hline 27 & 2011 & 07 & 12 & 43.9200 & 11.8610 & 5 & 4.15 & 282 & 47 & -95 & 110 & 43 & -84 \\
\hline 28 & 2018 & 03 & 05 & 43.9188 & 11.9537 & 2 & 3.74 & 164 & 49 & -92 & 347 & 41 & -88 \\
\hline 29 & 2013 & 07 & 11 & 43.8227 & 12.0575 & 6 & 4.04 & 138 & 49 & -100 & 333 & 42 & -79 \\
\hline 30 & 2014 & 10 & 17 & 43.7698 & 11.9333 & 14 & 3.45 & 83 & 80 & 155 & 177 & 65 & 11 \\
\hline 31 & 2014 & 12 & 19 & 43.6057 & 11.2582 & 5 & 4.05 & 343 & 85 & -19 & 75 & 71 & -174 \\
\hline 32 & 2015 & 03 & 04 & 43.6007 & 11.1788 & 7 & 3.68 & 350 & 86 & -5 & 80 & 85 & -176 \\
\hline 33 & 2014 & 12 & 19 & 43.6248 & 11.2322 & 5.6 & 3.52 & 263 & 86 & -169 & 172 & 79 & -4 \\
\hline 34 & 2019 & 06 & 15 & 42.9263 & 11.8853 & 8 & 3.41 & 14 & 64 & 54 & 253 & 44 & 140 \\
\hline 35 & 2016 & 05 & 31 & 42.7338 & 11.8697 & 7 & 3.58 & 264 & 73 & -154 & 166 & 66 & -19 \\
\hline 36 & 2013 & 03 & 18 & 43.1417 & 11.4342 & 13 & 3.67 & 338 & 78 & -34 & 76 & 57 & -165 \\
\hline 37 & 2016 & 03 & 04 & 43.4068 & 11.1877 & 8 & 3.45 & 249 & 67 & 140 & 357 & 53 & 29 \\
\hline 38 & 2018 & 05 & 01 & 43.2278 & 10.9613 & 8 & 3.74 & 82 & 88 & -130 & 349 & 40 & -4 \\
\hline 39 & 2018 & 04 & 11 & 43.1605 & 10.8447 & 7 & 3.64 & 146 & 79 & -17 & 240 & 73 & -169 \\
\hline 40 & 2014 & 08 & 09 & 43.5422 & 11.0407 & 9 & 3.43 & 74 & 88 & 170 & 165 & 80 & 2 \\
\hline 41 & 2016 & 10 & 25 & 43.6007 & 10.9940 & 9 & 3.88 & 260 & 89 & 158 & 350 & 68 & 1 \\
\hline
\end{tabular}



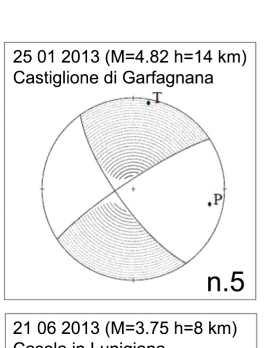
Casola in Lunigiana

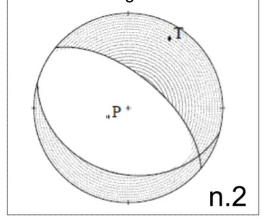

$29062013(\mathrm{M}=3.44 \mathrm{~h}=5.3 \mathrm{~km})$ Minucciano
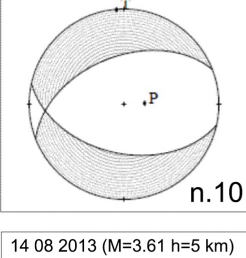
Minucciano

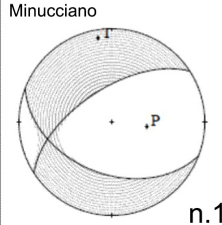

Sector I (northwestern Tuscany)

$21062013(\mathrm{M}=3.60 \mathrm{~h}=6 \mathrm{~km})$ Castiglione in Lunigian

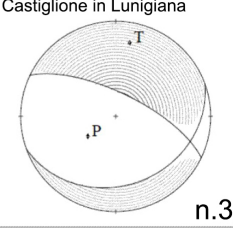

n.3

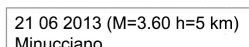
Minucciano
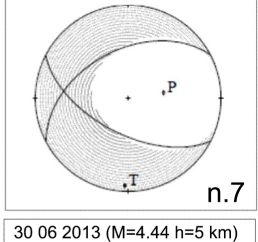
Minucciano

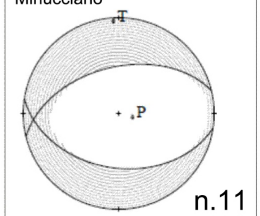

n.11

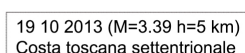
Costa toscana settentrionale

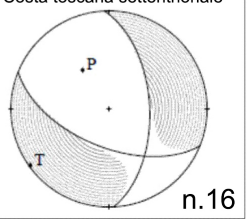

$21062013(\mathrm{M}=3.64 \mathrm{~h}=7 \mathrm{~km})$ Minucciano

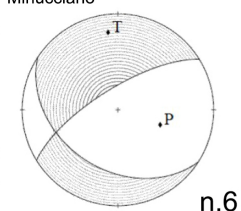

$23062013(\mathrm{M}=3.80 \mathrm{~h}=4 \mathrm{~km})$ Minucciano
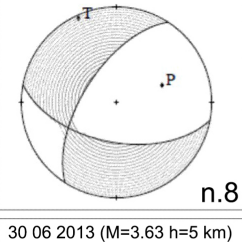
Minucciano

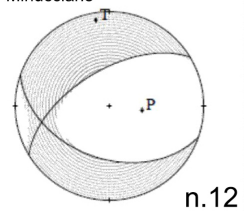

n.12
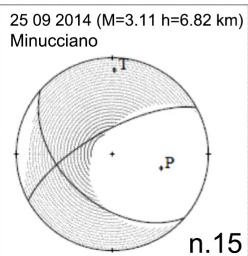

n.15
$21062013(\mathrm{M}=5.22 \mathrm{~h}=5 \mathrm{~km})$ Nordest di Carrara

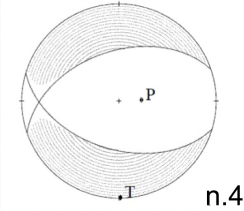

$\mathrm{n} .4$

$23062013(\mathrm{M}=4.40 \mathrm{~h}=6 \mathrm{~km})$ Minucciano

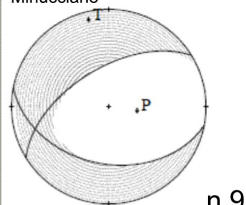

n.9

$08072013(M=3.48$ h=2 km) Minucciano

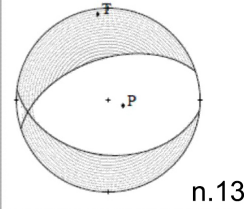

n.13

23062016 (M=4.04 h=2 km) Santo Stefano Magra

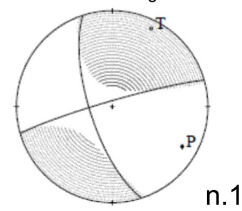

Sector II (Tuscan-Emilian-Romagna Apennines)
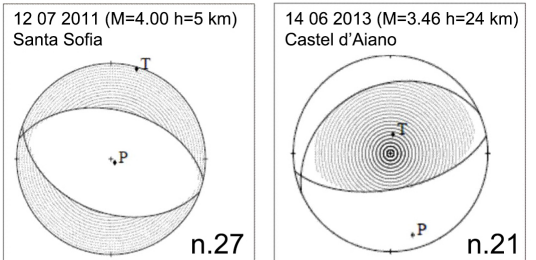

$11072013(\mathrm{M}=3.91 \mathrm{~h}=6 \mathrm{~km})$ Verghereto

n.27 $17102014(\mathrm{M}=3.53 \mathrm{~h}=14 \mathrm{~km})$
Chiusi della Verna

$23012015(\mathrm{M}=4.14 \mathrm{~h}=6 \mathrm{~km})$ Castiglione dei Pepoli

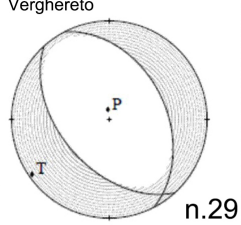

$07092014(M=4.08 \mathrm{~h}=15 \mathrm{~km})$
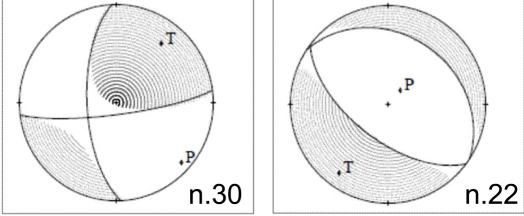

$23012015(\mathrm{M}=3.40 \mathrm{~h}=10 \mathrm{~km})$
Castiglione dei Pepoli
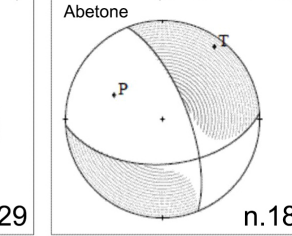

$17022015(M=3.85$ h=7 km)

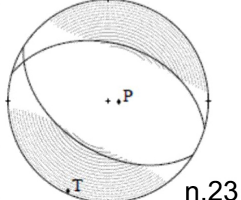

Firenzuola

16042015 (M=3.34 h=12 km)

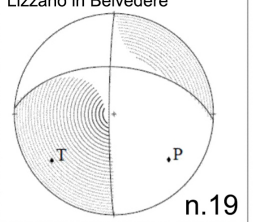

22072015 (M=3.85 h=11 km) Lizzano in Belvedere

05032018 (M=3.90 h=2 km) Santa Sofia
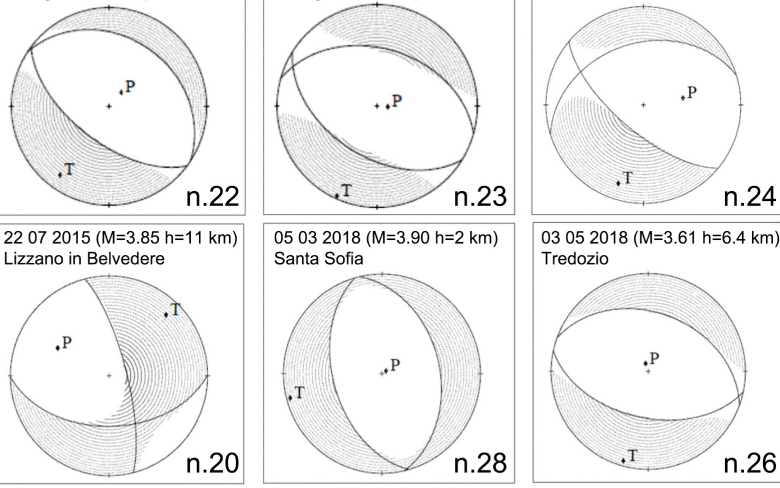

$03052018(\mathrm{M}=3.61 \mathrm{~h}=6.4 \mathrm{~km})$ Tredozio

$09122019(M=4.46 \mathrm{~h}=6 \mathrm{~km})$

01072018(

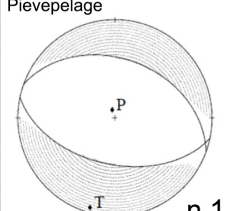

Scarperia $\mathrm{San}$ Piero
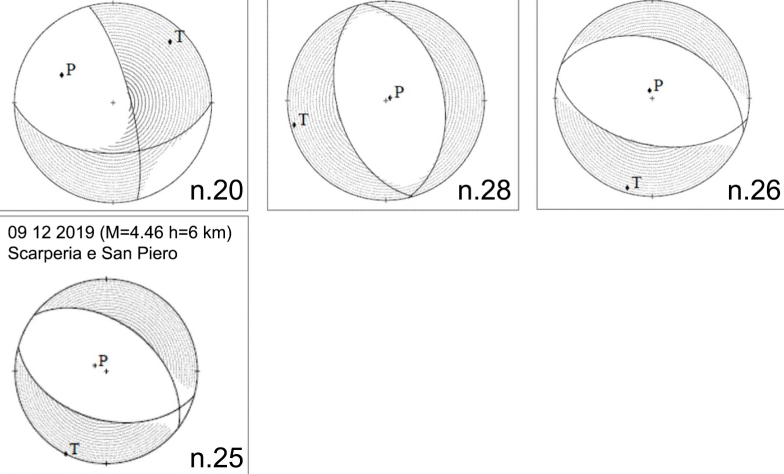
Sector III (Inner Tuscany)
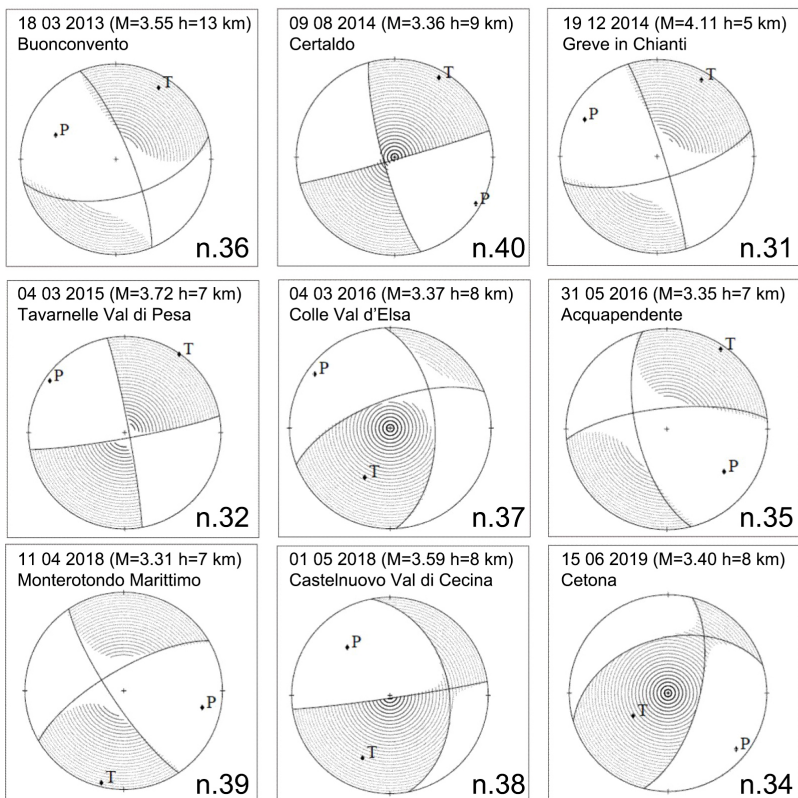

19122014 (M=3.53 h=5.6 km) San Casciano Val di Pesa

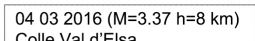
Colle Val d'Elsa

$31052016(\mathrm{M}=3.35 \mathrm{~h}=7 \mathrm{~km})$ Acquapendente
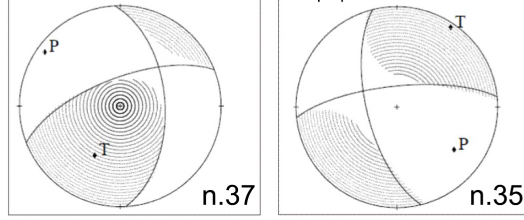

$01052018(M=3.59 \mathrm{~h}=8 \mathrm{~km})$ Castelnuovo Val di Cecina
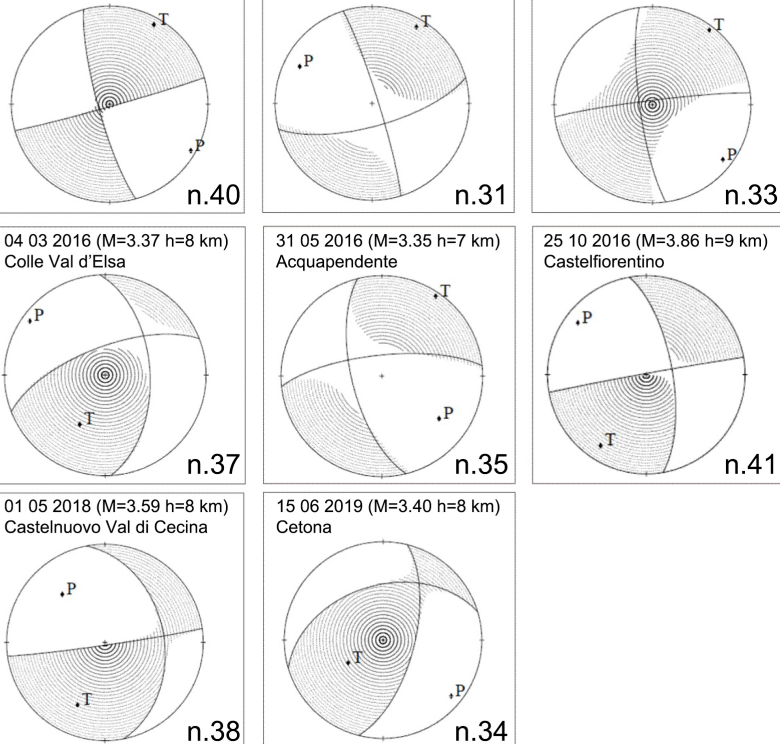

$25102016(M=3.86$ h=9 km) Castelfiorentino

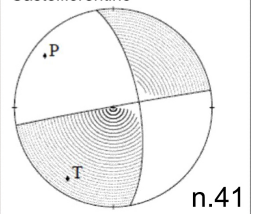

Cetona

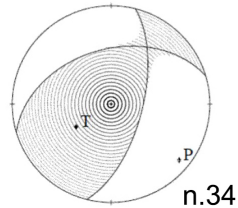

Figure A1. Stereographic projection of the focal sphere for the earthquake source mechanisms shown in Figure 4 (the related parameters are reported in Table A1). Each panel indicates the earthquake number, date, epicenter zone, magnitude (M) and hypocenter depth (h). The sketch shown the projection of the nodal planes and the poles of the $\mathrm{P}$ and $\mathrm{T}$ principal axes of the seismic moment tensor [115]. Note that $\mathrm{T}$ and $\mathrm{P}$ axes bisect the right dihedral angles delimited by the nodal planes. [166] first showed that the above axes coincide with the principal strain axes. Therefore the source mechanism describes the instantaneous deformation at the earthquake hypocenter, with the maximum and minimum lengthening corresponding to the $\mathrm{T}$ and $\mathrm{P}$ seismological axes respectively. Contrary to what is sometimes (improperly) reported in the literature, a single source mechanism poorly constrains the direction of the principal stress axes [124] [166] [167]. 